NBER WORKING PAPER SERIES

\title{
LARGE FISCAL EPISODES AND SUSTAINABLE DEVELOPMENT: SOME INTERNATIONAL EVIDENCE
}

\author{
Joshua Aizenman \\ Yothin Jinjarak \\ Hien Thi Kim Nguyen \\ Donghyun Park \\ Working Paper 28740 \\ http://www.nber.org/papers/w28740 \\ NATIONAL BUREAU OF ECONOMIC RESEARCH \\ 1050 Massachusetts Avenue \\ Cambridge, MA 02138 \\ April 2021
}

Financial support by the ADB is gratefully acknowledged. The views expressed herein are those of the authors and do not necessarily reflect the views of the National Bureau of Economic Research.

NBER working papers are circulated for discussion and comment purposes. They have not been peer-reviewed or been subject to the review by the NBER Board of Directors that accompanies official NBER publications.

(C) 2021 by Joshua Aizenman, Yothin Jinjarak, Hien Thi Kim Nguyen, and Donghyun Park. All rights reserved. Short sections of text, not to exceed two paragraphs, may be quoted without explicit permission provided that full credit, including $\odot$ notice, is given to the source. 
Large Fiscal Episodes and Sustainable Development: Some International Evidence Joshua Aizenman, Yothin Jinjarak, Hien Thi Kim Nguyen, and Donghyun Park NBER Working Paper No. 28740

April 2021

JEL No. E62,F15,F41,O11

\section{ABSTRACT}

This paper examines the association between episodes of large fiscal impulses (expansions and adjustments) and sustainable development indicators (prosperity, resilience, and inclusivity). We provide country studies of Chile, Poland, South Africa, and Thailand, examining the components of government expenses and tax revenues, and reporting four stylized patterns from the analysis. (i) Fiscal expansions led to higher growth rates and reduced negative trade-offs, e.g., pollution and poor-health mortalities associated with economic growth. (ii) Fiscal adjustments led to a more inclusive economy, lowered poverty headcounts, improved sanitation, and cleaner technology access. (iii) Fiscal expansions followed an increase in direct taxes (especially corporate taxes) and a decline in social contributions, and preceded a decline in other direct taxes and an increase in wage bills. (iv) Fiscal adjustments followed a decline in other direct taxes and social contributions, an increase in wage bills, and preceded a decline in government consumption expenditure and transfers. In light of these findings, the domestic resource mobilization should consider the time paths of the taxes and expenditure components to understand their empirical linkages with the sustainable development outcomes in the respective countries.

Joshua Aizenman

Economics and SIR

University of Southern California

University Park

Los Angeles, CA 90089-0043

and NBER

aizenman@usc.edu

Yothin Jinjarak

School of Economics and Finance

Victoria University of Wellington

PO Box 600

23 Lambton Quay, Wellington

New Zealand

yothin.jinjarak@vuw.ac.nz
Hien Thi Kim Nguyen

School of Economics and Finance

Victoria University of Wellington

Wellington 6140

New Zealand

hien.nguyen@vuw.ac.nz

Donghyun Park

Economics and Research Department

Asian Development Bank

Manila, Philippines

dpark@adb.org 


\section{INTRODUCTION}

This paper studies the intertemporal feedbacks between fiscal policy and sustainable development. We focus on the inclusivity of economic growth and domestic revenue mobilization around large fiscal mobilization episodes, including reforms of indirect taxes and exemptions, tax administration, and transfer programs. Inclusive growth reduces poverty, improves health and education, among others, and may enhance the tax capacity, spending efficiency, and resource mobilization (e.g., greater compliance, higher income, lower informality). In turn, higher tax mobilization may fund pressing social policies and redistribution, thereby deepening inclusive growth and better social infrastructure. Such associations are subject to structural factors, including governance, polarization, civil wars and conflicts, ethnic and religious fragmentation, quality of institutions, a share of manufacturing, farming, commodity dependence, and urbanization rates.

To deepen our understanding amid the challenges posed by multidimensional data requirements, we provide country studies that are combined with a panel estimation of selected emerging markets. We ask three questions. The first is the relationship between economic structure and the composition of government revenues and expenses. Second, we address the association between episodes of large fiscal impulses (expansions and adjustments) and sustainable development outcomes (prosperity, inclusivity, and resilience). Third, we ask whether past changes in the budget's specific components led to fiscal expansions and adjustments, which relied on future changes in certain budget items.

After putting together the necessary data, we identify Chile, Poland, South Africa, and Thailand as the emerging markets that provide sufficient fiscal aggregates and represent a diverse sample set for the analysis. For these countries, a third of gross domestic product (GDP) is the industry, and more than half are services (as of 2018; World Bank (2020)). Despite the similarity, there are structural differences. Chile's largest exports are metals, minerals, and agricultural products; South Africa's largest exports are stone, minerals, and agricultural products (as of 2018; The Growth Lab at Harvard University (2019)): the fiscal stance is vulnerable to commodity price fluctuations. Poland's largest exports are machinery, services, and agricultural products; Thailand's largest exports are services, machinery, electronics, vehicles, and chemicals: the fiscal conditions are sensitive to global industrial production and related supply-chain services. Thus, different terms of trade shocks are responsible for large episodes of fiscal expansions and adjustments across these economies. There are also differences in their politico- 
economic structure, i.e., liberal versus conservative tendency and single-party versus coalition government. These subtleties are beyond the scope of our paper.

The analysis proceeds with the decomposition of fiscal revenues and expenses and their linkages with sustainable development. The estimation then tests these linkages' strengths, identifying prevalent useful feedback as the guidelines for dealing with the present and future challenges.

We find some stylized patterns in the sample countries. (i) Fiscal expansions led to higher growth rates and reduced negative trade-offs, e.g., pollution and poor-health mortalities associated with economic growth. (ii) Fiscal adjustments led to a more inclusive economy, lowered poverty headcounts, improved sanitation, and cleaner technology access. (iii) Fiscal expansions followed an increase in direct taxes (especially corporate taxes) and a decline in social contributions, and preceded a decline in other direct taxes and an increase in wage bills. (iv) Fiscal adjustments followed a decline in other direct taxes and social contributions, an increase in wage bills, and preceded a decline in government consumption expenditure and transfers. In light of these findings, the domestic resource mobilization should consider the time paths of the taxes and expenditure components to understand their empirical linkages with the sustainable development outcomes in the respective countries.

The key takeways are (i) Countries have distinct fiscal challenges, underlined by their economic and institutional structures. Value-added tax revenues have accounted for $30 \%-60 \%$ of total revenues in the countries sampled. Domestic public resources of commodity-exporting countries are vulnerable to commodity terms of trade shocks. The fiscal conditions of manufacturing-exporting countries are dependent on the global value chains, the global business cycle, and supporting services. (ii) The associations between fiscal expenses, taxes, and sustainable development outcomes differ across countries. A focal study on fiscal episodes (loose/expansion versus tight/adjustment) is the low-hanging fruit in understanding the linkages between fiscal aggregates and the role of domestic resource mobilization (DRM) in inclusive growth and sustainable development. In the country case studies, large fiscal episodes accounted for $16 \%$ of the sample periods. (iii) DRM should consider the time paths of the taxes and expenditure components to understand their empirical linkages with the sustainable development outcomes in the respective countries. (iv) It is practically useful to have a template for tracing the linkages between fiscal stance and the sustainable development outcomes. Future analysis should adjust to the data available, recognizing the constraints, i.e., if unemployment statistics are not a suitable indicator for accounting for the economic cycles in some countries, one can look at proxies like 
employment, electricity consumption, etc. (v)More data may shed more light on correlations between the fiscal conditions and DRM for sustainable development in the coming years. Pre-coronavirus disease (COVID-19), the size of fiscal impulses to gross domestic product in the countries studied was already in the range of $1.4 \%-4.8 \%$. Given the larger prospective fiscal stimuli across the developing countries, the public and private debts and quality of governance stand out as the emergent issues in the post-COVID19.

Section II describes the data. Section III discusses fiscal aggregates and sustainable development and follows with the estimation of the linkages in section IV. The conclusion is in section V.

\section{DATA}

Data on the main components of the general government spending are from Government Finance Statistics (International Monetary Fund, 2020), including wage bills (Wage), non-wage expenditure (Nonwage), subsidies to firms (Subsidies), and expenditure on social benefits (Transfers); all in percent of GDP. Because data on fixed capital consumption are not available for Thailand and only available for South Africa from 2003, we exclude it from the study. This exclusion should not influence our analysis as the fixed capital consumption is only a minor part of the general government expenditure $(0.93 \%$ in Chile 2000-2018, 2.45\% in Poland 1995-2018, and 0.7\% in South Africa 2003-2018). Following the literature, we also exclude interest expense to focus on the discretionary change of fiscal impulse. Our data indicate that the interest expense accounts for a small fraction of the general government expenses $(0.76 \%$ in Chile 2000-2018, 2.78\% in Poland 1995-2018, 3.81\% in South Africa 1996-2018, and 1.1\% in Thailand 2000-2018).

We use the ICTD/UNU-WIDER (2020) database for the main components of total tax revenue. The data include personal income taxes $(P I T)$, corporate taxes $(C I T)$, payroll and workforce taxes and property taxes (Other), indirect taxes (INDT), and social security contributions (SSC); all in percent of GDP. For Chile, we interpolate the 1993-2005 non-resource CIT from the total CIT-total income and profit taxes on corporations, including taxes on resource firms-over the 1993-2005 period, using the 2006-2018 ratio of the non-resource $C I T$ to total $C I T .^{1}$ 1 Specifically, $C I T_{\text {Chile }, t}=\left(\frac{1}{13} \sum_{i=2006}^{2018} \frac{C I T_{\text {Chile }, i}}{T C I T_{\text {Chile }, i}}\right) * T C I T_{\text {Chile,t }}$, where $t=1993-2005 ; T C I T$ is total income and profit taxes
on corporations, including taxes on resource firms. 
We calculate the primary balance as follows:

$$
\begin{aligned}
& \text { - (Total) Tax revenue (\% of GDP) }=\text { PIT + CIT + Other + INDT + SSC } \\
& \text { - } \quad \text { Primary expenses }(\% \text { of GDP) }=\text { Wage + Non-wage + Subsidies + Transfer } \\
& \text { - } \quad \text { Primary deficit }(\% \text { of GDP) = Primary expenses - Total (tax) revenue }
\end{aligned}
$$

Our analysis considers economic growth, taking into account its inclusivity and sustainability. For comprehensiveness, we use 17 Sustainable Development Goals (SDGs) indicators, covering poverty headcount ratio (Poverty); population share undernourished (Undernourishment); mortality ratio from cardiovascular disease (CVD); cancer, diabetes, or chronic respiratory disease (CRD) between age 30 and age 70 (Mortality); enrollment ratio to pre-primary school (Enrollment); proportion of seats held by women in national parliaments (Women power); population share with access to basic sanitation services (Sanitation); population share with access to clean fuels and technologies for cooking (Fueltech); youth population share not in education, employment or training (Non-education); fixed broadband subscriptions (Broadband); mean consumption of bottom $40 \%$ of population (Bottom consumption); exposure to PM2.5 air pollution (Pollution); carbon dioxide damage (Carbon dioxide damage); number of displaced persons associated with disasters (Displacement); marine-protected areas (Marine); terrestrial protected areas (Terrestrial); bribery incidence experienced by firms (Bribery); and personal remittances (Remittances). Details of these indicators are in the Appendix. We collect the annual data from World Development Indicators (World Bank, 2020) and use linear interpolation for the missing data. Our final sample of fiscal and sustainable-development variables includes Chile 2000-2018, Poland 1995-2018, Thailand 2000-2018, and South Africa 1996-2018.

\section{FISCAL AGGREGATES AND SUSTAINABLE DEVELOPMENT}

Section III looks at the structure of total tax revenue and primary expenses across countries. Figure 1 plots the time paths of fiscal components (as a share of GDP) during 2000-2018 (Poland and South Africa data went back to 1995). We also compute the variations (changes and standard deviation [s.d.]) of total tax revenue, primary expenses, and each country's fiscal components over the sample period. 
Figure 1: Fiscal Expenses and Revenues, 2000-2018

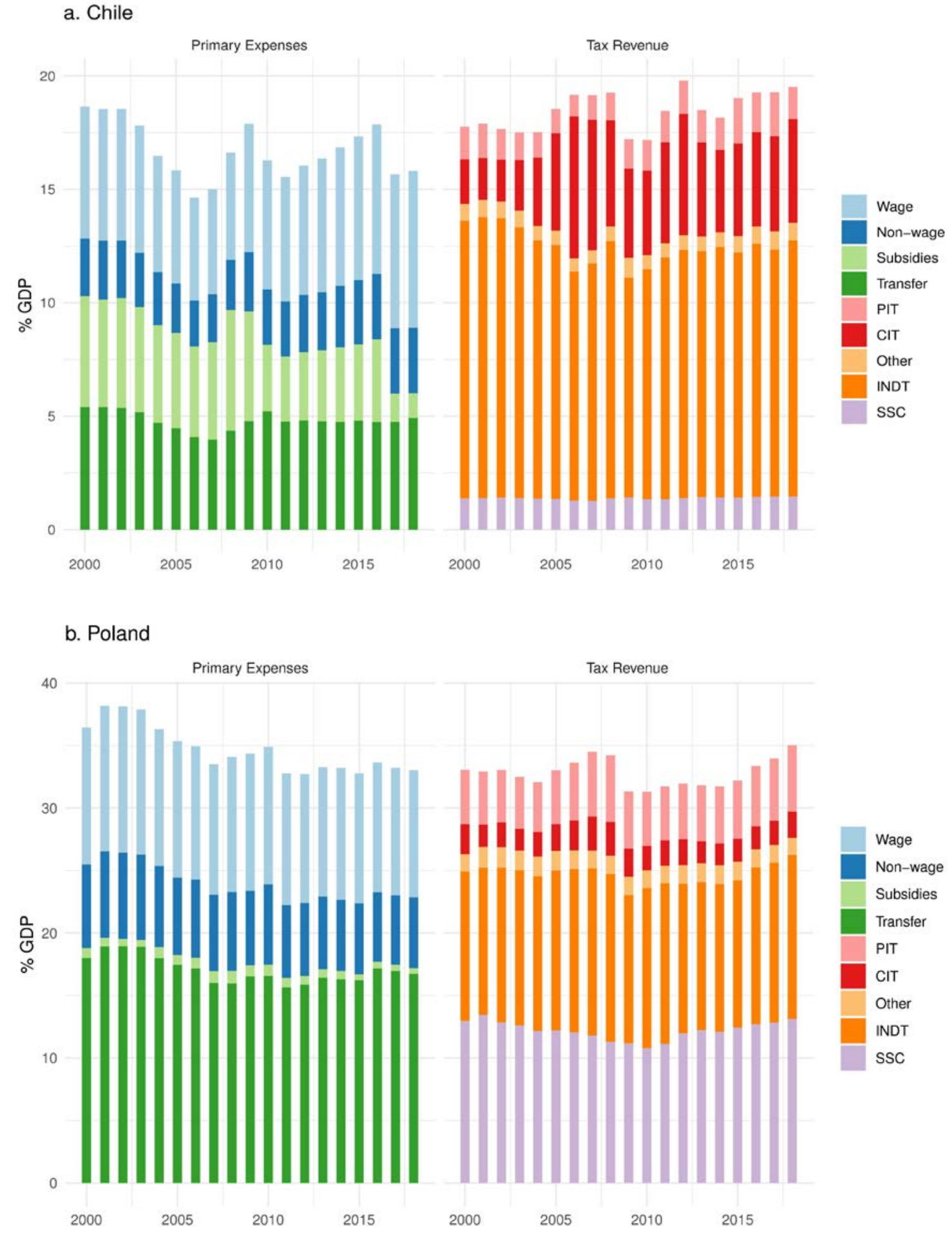




\section{c. South Africa}

Primary Expenses

Tax Revenue

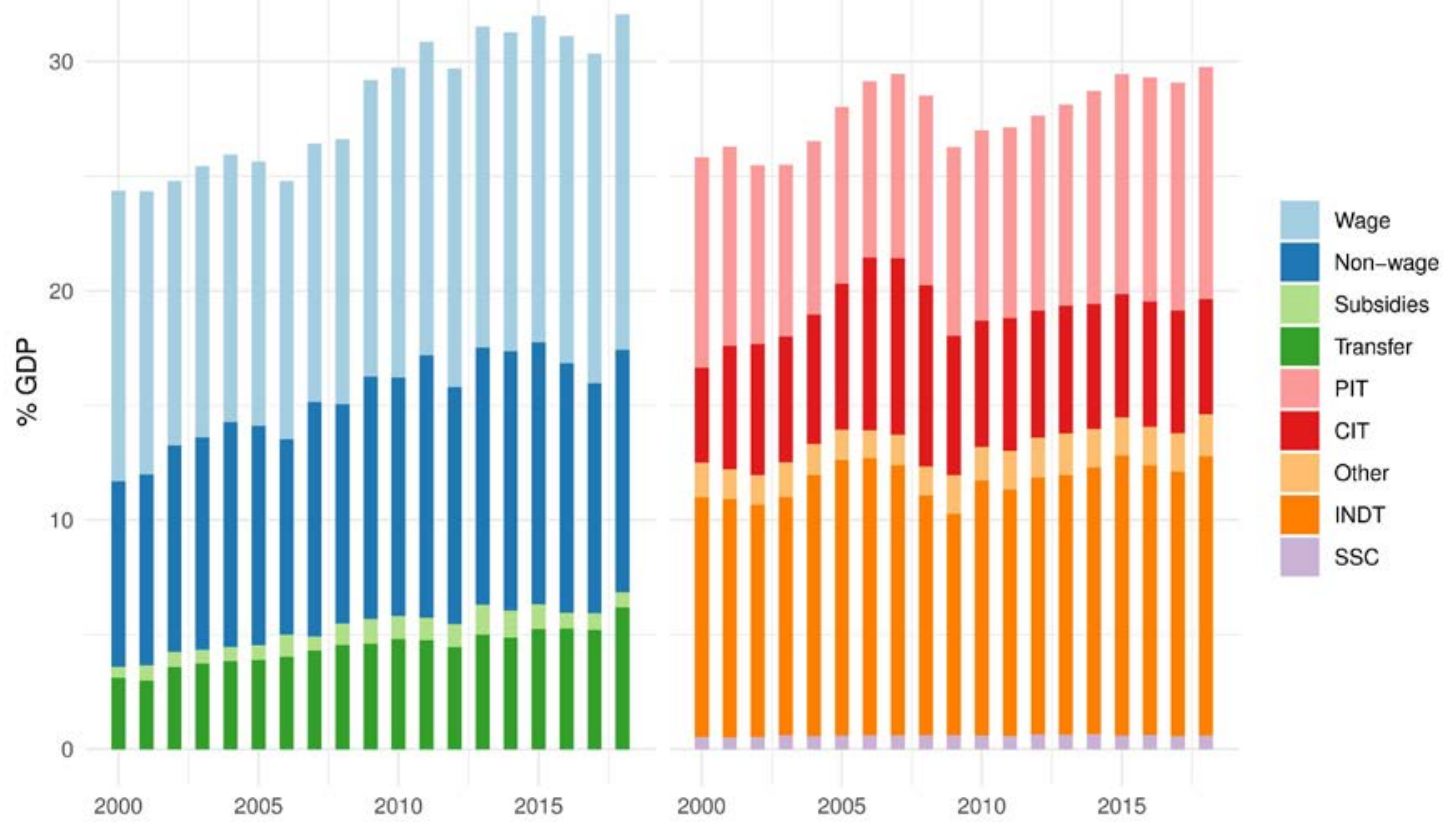

d. Thailand

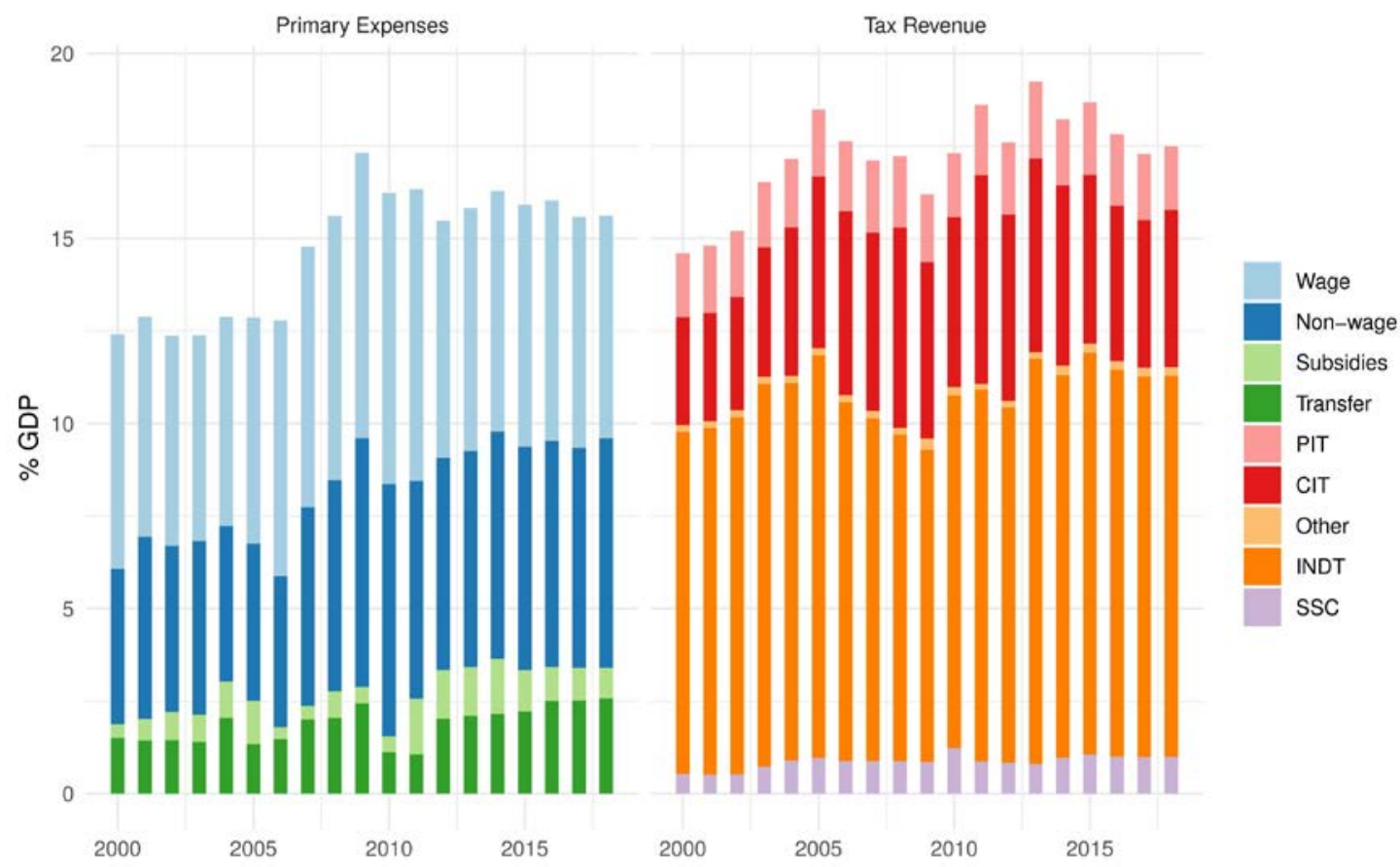

Wage $=$ compensation on employees, Non-wage $=$ expense on good and services, Subsidies $=$ subsidies to firms, Transfer = expense on social benefits, $\mathrm{PIT}=$ non-resource personal income taxes, $\mathrm{CIT}$ = non-resource corporate income taxes, Other $=$ taxes on payroll and workforce and taxes on the property, INDT = indirect taxes, SSC = social security contributions. Notes:

1. Each component is a share of GDP. 
2. Taxes/gross domestic product increased in the developing countries sampled; Chile and Thailand more on the CIT and INDT (value-added tax, consumption tax), while Poland and South Africa more on PIT and INDT.

Sources: Internation Monetary Fund (2020), and ICTD/UNU-WIDER (2020).

From Figure 1, Chile (Figure 1a) saw the primary expenses decreased (2.8\% [s.d. 1.2\%]), while the total tax revenue to GDP increased (1.8\% [s.d. 0.8\%]) during 2000-2018. The expenditure on subsidies to firms decreased (3.8\% [s.d. 1.2\%]), and the wage bills increased (1.1\% [s.d. 0.7\%]). The shares of non-wage bills and transfer expenses remained stable over time [s.d. $0.3 \%$ and $0.4 \%$, respectively]. The corporate income taxes to GDP increased (2.6\% [s.d. 1.3\%]), while the indirect taxes decreased (1\% [s.d. $0.8 \%$ ]). Other tax components' contributions remained largely unchanged.

Poland (Figure 1b) saw the primary expenses decreased (3.4\% [s.d. 1.9\%]) and the total tax revenue to GDP increased (2\% [s.d. 1.1\%]). The transfer and non-wage bills to GDP decreased (1.3\% [s.d. 1\%] and 1\% [s.d. 0.5\%], respectively). The personal income taxes and indirect taxes to GDP increased (1\% [s.d. $0.4 \%-0.6 \%])$. Other expenses and tax components were relatively stable during the 2000-2018 period. South Africa (Figure 1c) saw both primary expenses to GDP and tax revenue to GDP increased (7.7\% [s.d. 2.9\%] and 3.9\% [s.d. 1.5\%], respectively). Transfer expenses to GDP increased (3.1\% [s.d. 0.8\%]) and the non-wage bills increased (2.5\% [s.d. 1\%]). The indirect taxes and personal income taxes to GDP increased (1.7\% [s.d. 0.8\%] and $1 \%$ [s.d. 0.8\%], respectively.

Thailand (Figure 1d) saw both primary expenses to GDP and total tax revenue to GDP increased (3\% [s.d. $1.7 \%$ ] and $3 \%$ [s.d. 1.3\%], respectively). The non-wage bills to GDP increased the largest (2\% [s.d. 0.9\%]), followed the share of transfer expenditure to GDP (1\% [s.d. 0.5\%]). The corporate income taxes to GDP increased most significantly (1.3\% [s.d. 0.8\%]), followed by indirect taxes to GDP (1.1\% [s.d. 0.7\%]). The shares of other expenses elements are largely unchanged. 
Figure 2: Components of Revenues and Expenses, 2000-2018

a. Chile 2000-2018
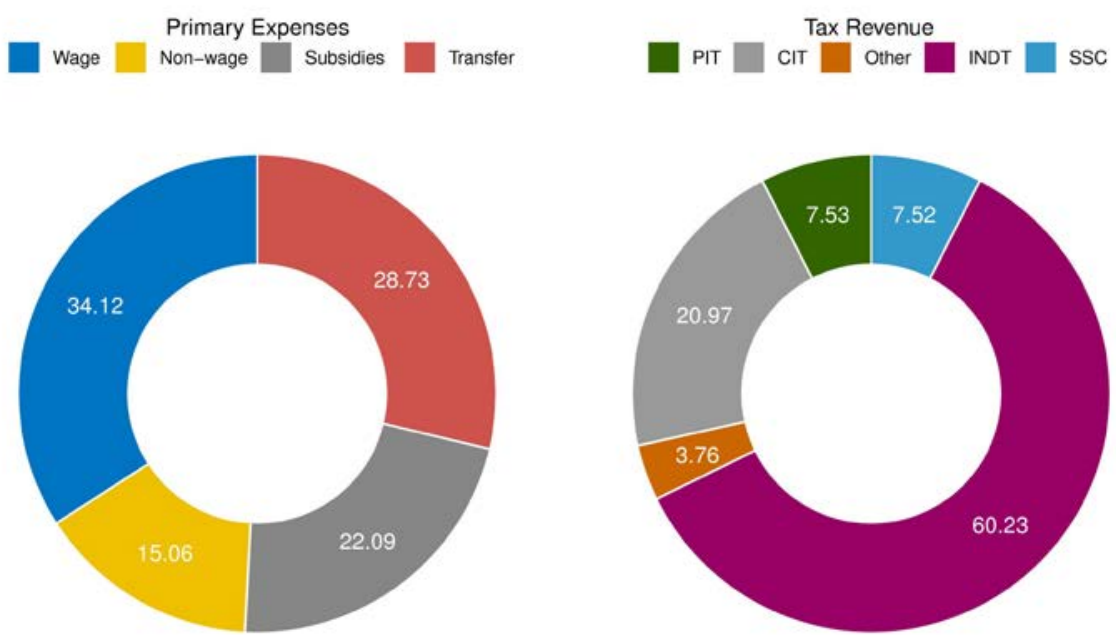

b. Poland $1995-2018$
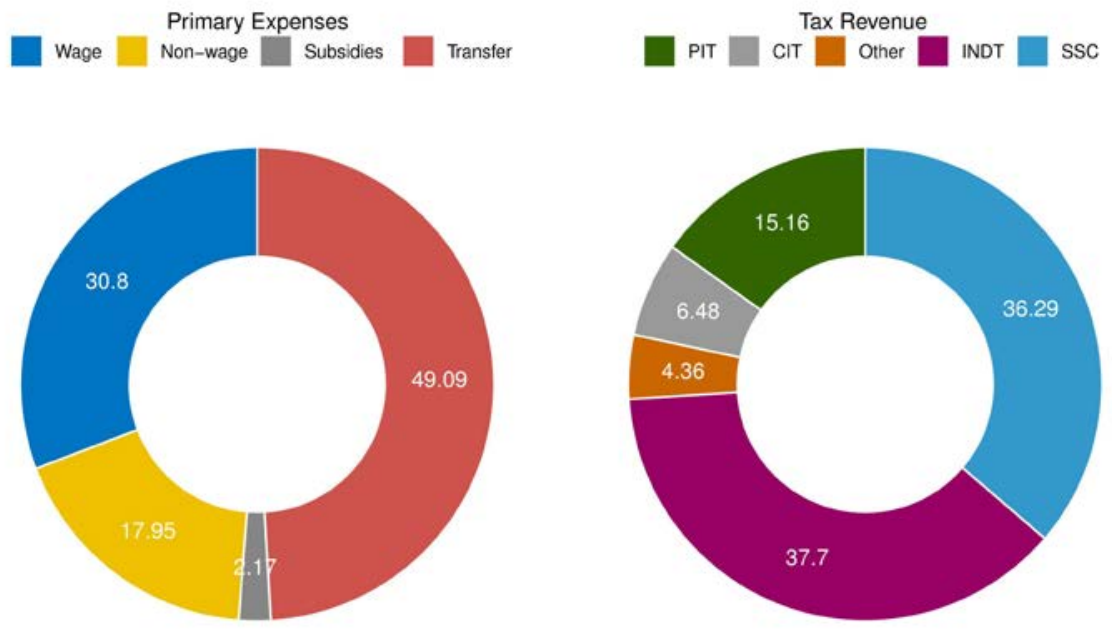

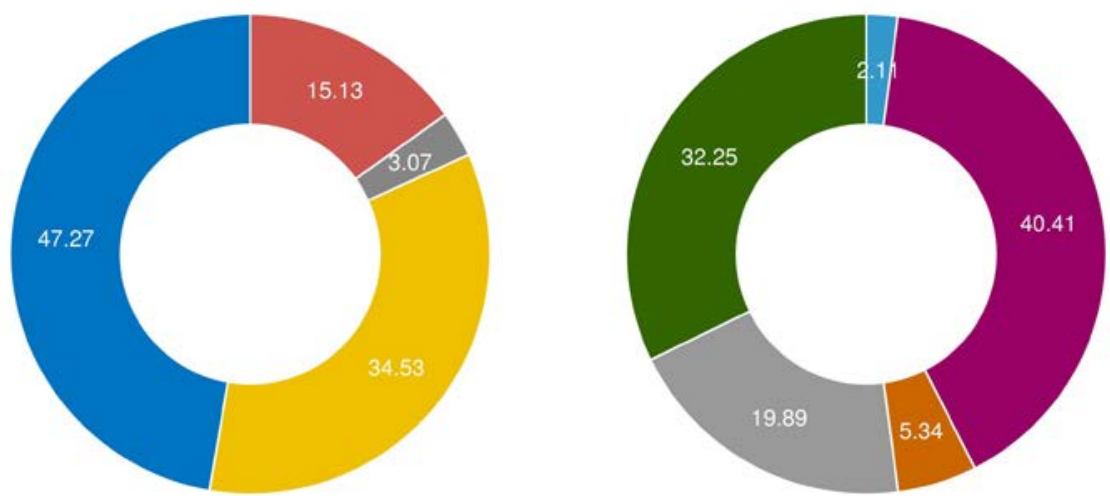

d. Thailand 2000-2018
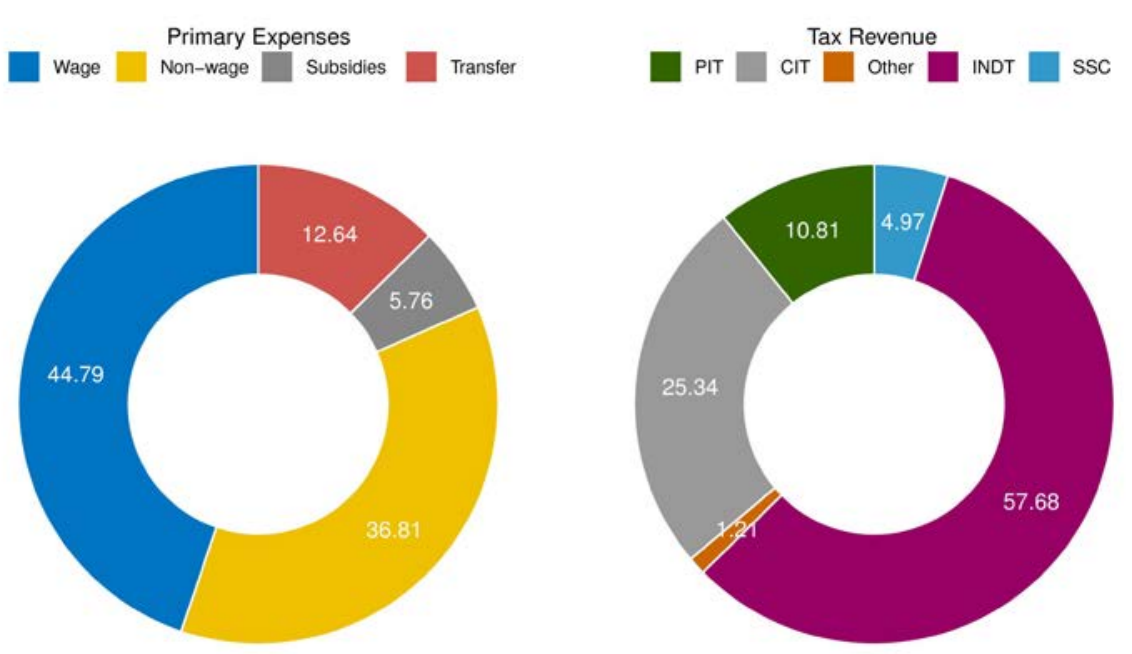

Wage $=$ compensation on employees, Non-wage = expense on good and services, Subsidies = subsidies to firms, Transfer = expense on social benefits, $\mathrm{PIT}=$ non-resource personal income taxes, $\mathrm{CIT}$ = non-resource corporate income taxes; Other = taxes on payroll and workforce and taxes on the property, INDT = indirect taxes, SSC = social security contributions. Notes:

1. Units are the percentage of primary expenses (left panel) and the total tax revenue (right panel). Primary expenses exclude interest expense and fixed capital consumption.

2. Wage bills accounted for a significant share in the primary deficits, except Poland, where transfers dominated the total government expenditures. Indirect taxes accounted for a third to half of the revenues in all countries.

Sources: Internation Monetary Fund (2020), and ICTD/UNU-WIDER (2020). 
Figure 2 reports each tax component's contribution to the total tax revenue and each expenditure component to the primary expenses. For Chile (Figure 2a), wage bills (34\%) account for the largest share of expenses, followed by expenditure on transfer expense (28\%), subsidies to firms (22\%), and non-wage bills (15\%). Indirect taxes (60\%) and corporate income taxes (20\%) account for most of the total tax revenue.

For Poland (Figure 2b), transfer expense (49\%) accounts for the largest share of primary expenses, followed by wage bills (30\%) and non-wage expenditures (17\%). Poland's tax structure has a large share of indirect taxes (37\%) and social contributions (36\%) in total tax revenue.

For South Africa (Figure 2c), wage bills (47\%) and non-wage expenditures (34\%) are the main components of the primary expenses. Indirect taxes (40\%) account for the largest share of total tax revenue, followed by personal income taxes (32\%) and corporate income taxes (19\%).

For Thailand (Figure 2d), wage bills (44\%) are the largest expenditure components, followed by nonwage expenditures (36\%). Indirect taxes (57\%) account for the largest share of total tax revenue, followed by corporate income taxes (25\%) and personal income taxes (10\%).

Figure 3: Fiscal Components and Development Dimensions

(Sustainable Development Goals)

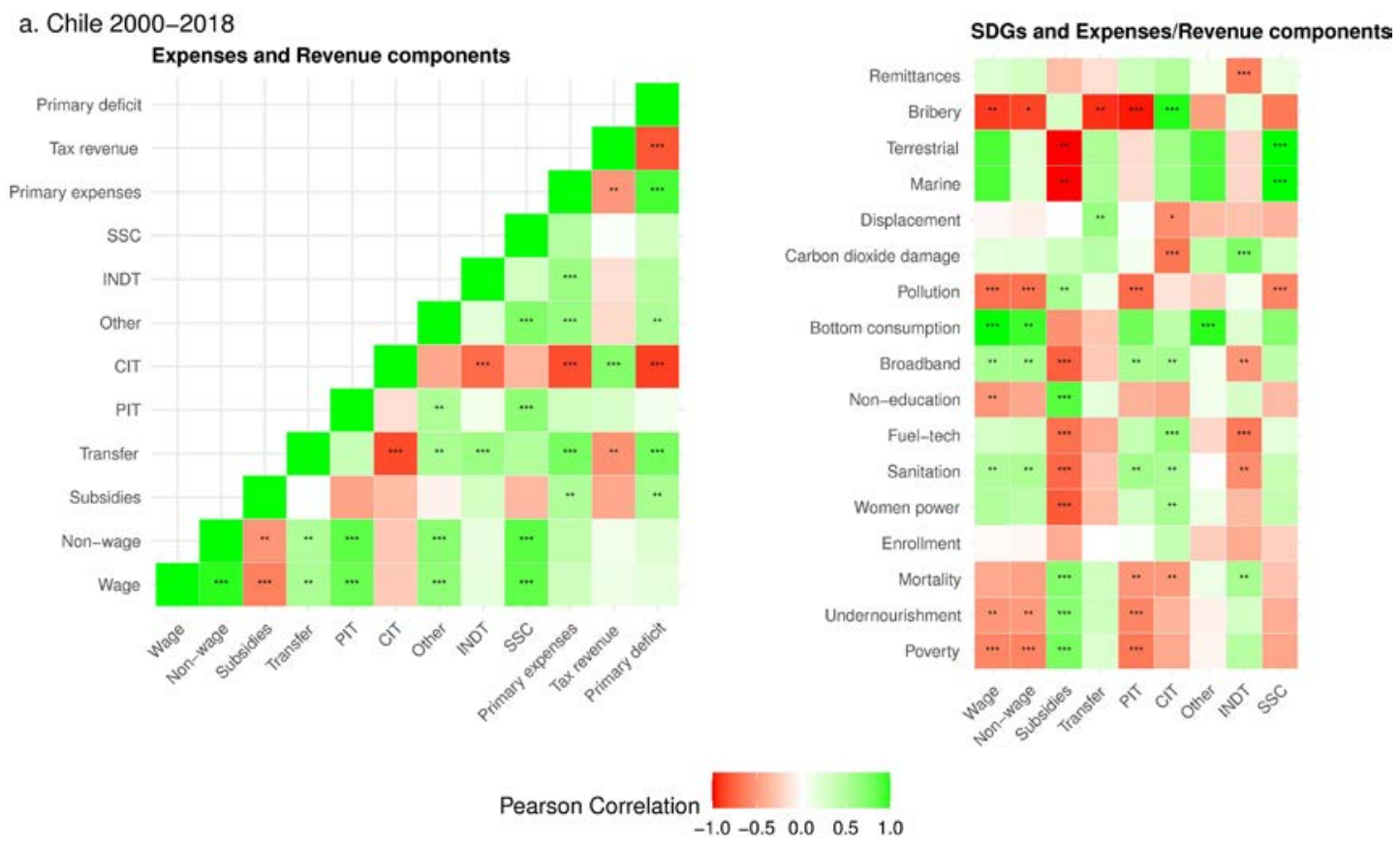


b. Poland 1995-2018

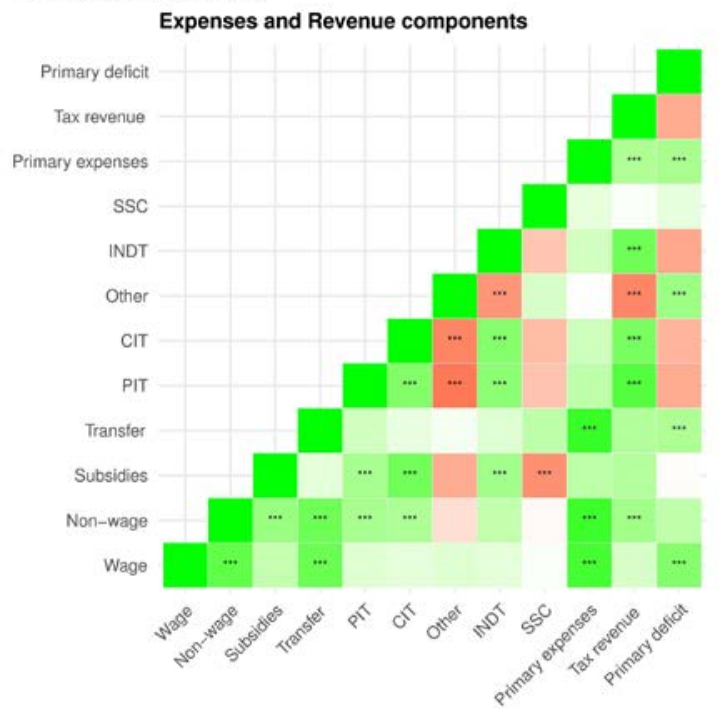

SDGs and Expenses/Revenue components

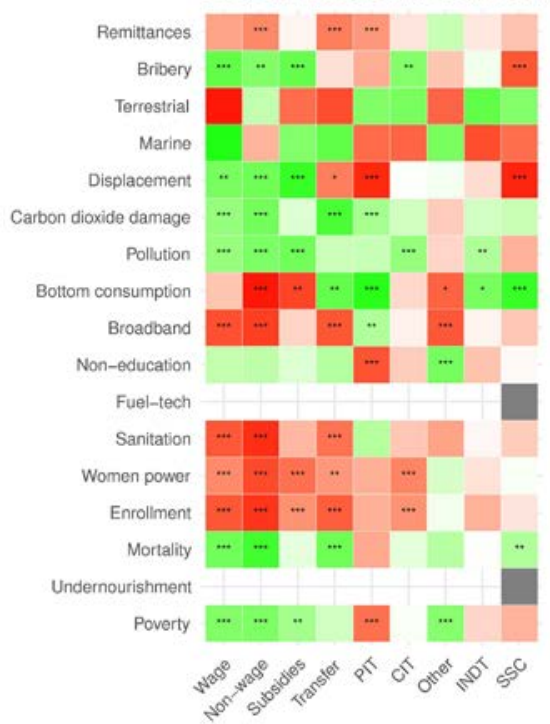

Pearson Correlation $\begin{array}{llllll} & & & & \\ -1.0 & -0.5 & 0.0 & 0.5 & 1.0\end{array}$

c. South Africa 1996-2018

Expenses and Revenue components

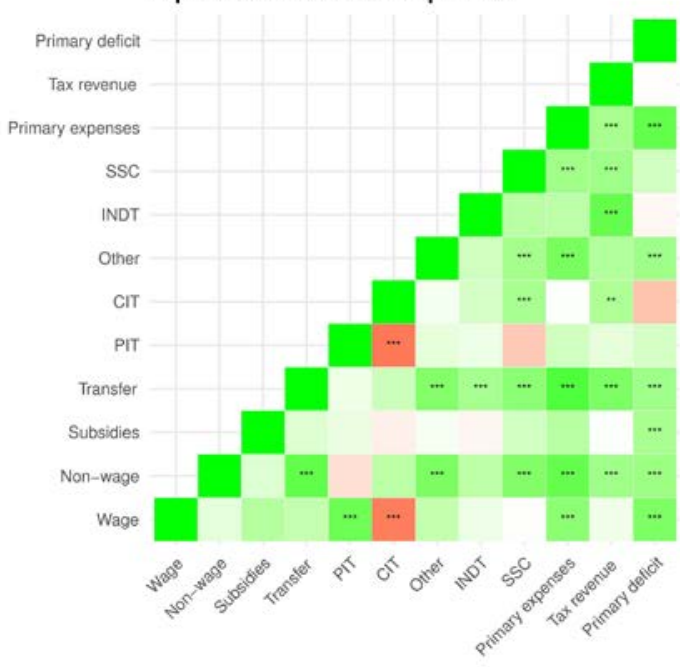

SDGs and Expenses/Revenue components

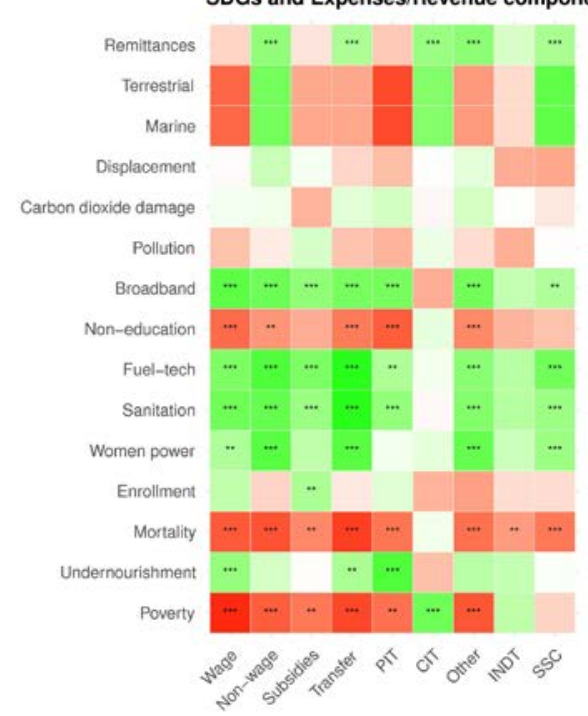

Pearson Correlation 
d. Thailand $2000-2018$

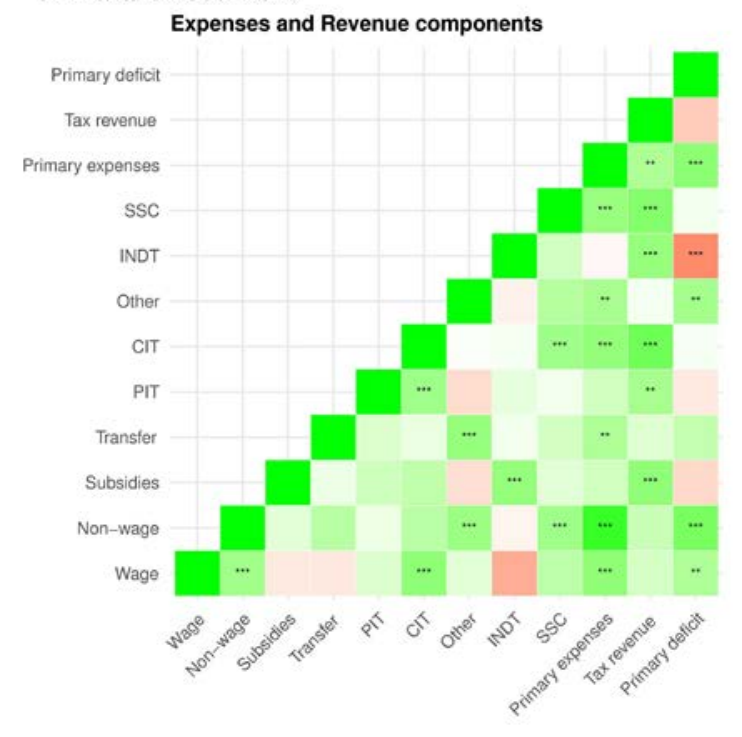

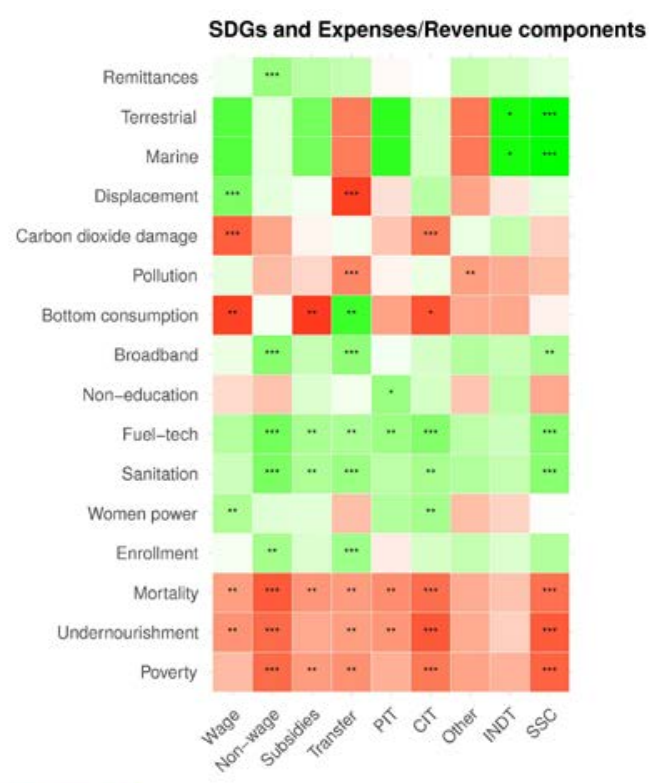

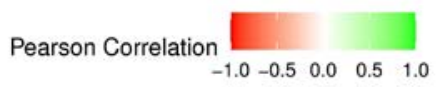

Wage $=$ compensation on employees, Non-wage $=$ expense on good and services, Subsidies $=$ subsidies to firms, Transfer = expense on social benefits, $\mathrm{PIT}=$ non-resource personal income taxes, CIT = non-resource corporate income taxes; Other $=$ taxes on payroll and workforce and taxes on the property, INDT = indirect taxes, SSC = social security contributions. Notes:

1. Statistical associations greater than 0.5 have star(s) in the heatmaps; ***, **, * signifies $1 \%, 5 \%, 10 \%$ level of significance.

2. The associations between fiscal expenses, taxes, and sustainable development outcomes differed across Chile, Poland, South Africa, and Thailand. The differences motivate a focal study on fiscal episodes as the lowest-hanging fruit in understanding the empirical linkages between fiscal aggregates and domestic resource mobilization's role in inclusive growth and sustainable development.

Sources: Internation Monetary Fund (2020), and ICTD/UNU-WIDER (2020).

Figure 3 shows the correlation coefficients between total tax revenue, primary expenses, primary deficit, the fiscal components, and 17 SDGs. For Chile (Figure 3a), total tax revenue is negatively associated with primary expenses and primary deficit. Corporate income taxes and Transfer components represent this association with the primary deficit. Given that corporate income tax is the second-largest component of revenue, its association with carbon dioxide damage (neg.), fuel/clean technology (neg.), and bribery (pos.) are favorable. The association between indirect taxes (the largest component of revenue) with remittances (neg.), carbon dioxide damage (pos.) and fuel/clean technology (neg.) suggest that a better understanding of their linkages should be useful for domestic resource mobilization. 
For Poland (Figure 3b), primary expenses are positively associated with total tax revenues and primary deficit. Transfer and wage-bill components represent this association with the primary deficit. Given that social security contributions are the second-largest component of revenue, its association with bribery (neg.), displacement (neg.), and bottom-income consumption (pos.) are favorable. The association between transfers (the largest component of expenses) with carbon dioxide damage (pos.), broadband access (neg.), sanitation quality (neg.), enrollment (neg.), and mortality (pos.) suggest that a better understanding of their linkages should be useful for domestic resource mobilization.

For South Africa (Figure 3c), primary expenses are positively associated with total tax revenues and primary deficit. Transfers, subsidies, wage-bill, and non-wage components represent this association with the primary deficit. The association between transfers and broadband access (pos.), non-education

ratio (neg.), fuel/clean technology (pos.), sanitation quality (pos.), women power/gender equity (pos.), mortality (neg.), and poverty (neg.) are favorable.

For Thailand (Figure 3d), primary expenses are positively associated with total tax revenues and primary deficit. Indirect-tax, wage-bill, and non-wage components represent this association with the primary deficit. The association between corporate income taxes (the second-largest revenue component) and carbon dioxide damage (neg.), fuel/clean technology (pos.), mortality (neg.), undernourishment (neg.), and poverty (neg.) are favorable. A weak association between indirect taxes (the largest revenue component) and SDG outcomes suggests their efficient domestic resource mobilization utilization should be useful.

\section{LINKING FISCAL EPISODES TO SUSTAINABLE DEVELOPMENT}

\section{A. Identifying Fiscal Episodes}

Following Alesina and Ardagna (2010) and Alesina and Perotti (1995), we define fiscal episodes using the significant change in the primary deficit (as a share of GDP) from the previous year. The underlying assumption is that the unemployment rate remained stable in period $t$ as in period $t$-1. According to Blanchard (1993), this approach takes the previous year as the benchmark period ( $t-1)$ and estimates the government expenses and tax revenue in the current year $(t)$, thereby filtering out the variations in fiscal variables induced by business cycle fluctuations. Subject to data availability, we follow this approach for simplicity, avoiding the challenges posed by country-specific calculation of potential outputs.

To define the cyclically adjusted variables and episodes of large fiscal impulse: 
- $\quad$ Cyclically adjusted Primary expenses (\% of GDP) = Cyclically adjusted Transfer $+($ Wage + Non-wage + Subsidies)

- $\quad$ Cyclically adjusted Total tax revenue (\% of GDP) = Cyclically adjusted PIT + Cyclically adjusted CIT + Other + Cyclically adjusted INDT + Cyclically adjusted SSC

- $\quad$ Cyclically adjusted Primary deficit (\% of GDP) = Cyclically adjusted Primary expenses Cyclically adjusted Total tax revenue

- $\quad$ Fiscal impulse $t$ (\% of GDP) = Cyclically adjusted Primary deficit ${ }_{t}-$ Primary deficit $_{t-1}$

We correct each of the fiscal variables at period $t$ (denoted as $X_{t}$ ) the variations caused by cyclical factors. For each country in the sample, we first regress each fiscal variable $\left(X_{t}\right)$ on a time trend $\left(T R E N D_{t}\right)$ and the unemployment rate $\left(U_{t}\right)$.

$$
X_{t}=\alpha_{0}+\alpha_{1} \operatorname{TREND} D_{t}+\alpha_{2} U_{t}+\varepsilon_{t}
$$

Next, we estimate what each fiscal variable would be in period $t$ if the unemployment rate were to remain the same as in the previous year $\left(U_{t-1}\right)$, i.e., the cyclically adjusted fiscal variable.

$$
X_{t}\left(\text { at } U_{t-1}\right)=\widehat{\alpha_{0}}+\widehat{\alpha_{1}} T R E N D_{t}+\widehat{\alpha_{2}} U_{t-1}+\widehat{\varepsilon_{t}}
$$

, where the terms, $\widehat{\alpha_{0}}, \widehat{\alpha_{1}}, \widehat{\alpha_{2}}$, and $\widehat{\varepsilon_{t}}$ are coefficient estimates.

Having estimated $\operatorname{Transfer}_{t}\left(\right.$ at $\left.U_{t-1}\right), \operatorname{PIT}_{t}\left(\right.$ at $\left.U_{t-1}\right), \quad \operatorname{CIT}_{t}\left(\right.$ at $\left.U_{t-1}\right), \quad \operatorname{INDT}_{t}\left(\right.$ at $\left.U_{t-1}\right)$, and $S_{S C}\left(\right.$ at $\left.U_{t-1}\right)$, we calculate Primary expenses ${ }_{t}\left(\right.$ at $\left.U_{t-1}\right)$, Total tax revenue ${ }_{t}\left(\right.$ at $\left.U_{t-1}\right)$, and then Primary deficit $t_{(}\left(a t U_{t-1}\right)$. The Fiscal impulse at period $t$ is the difference between the cyclically adjusted primary deficit at period $t\left[\right.$ Primary deficit $_{t}\left(\right.$ at $\left.\left.U_{t-1}\right)\right]$ and the actual primary deficit at period $t-1\left[\right.$ Primary de ficit $\left._{t-1}\right]$.

We estimate fiscal impulse using the balanced data of expenses and tax revenue components in each country: Chile 2000-2018, Poland 1995-2018, South Africa 1996-2018, and Thailand 2000-2018. We have 81 observations of fiscal impulse in the four sample countries; the mean fiscal impulse is $0.036 \%$ of GDP and a standard deviation of $1.308 \%$ of GDP. Appendix Table A1 provides more detailed statistics. We identify episodes of large fiscal impulse (discretionary fiscal policy): fiscal adjustment and fiscal stimuli as follows:

- $\quad$ strong fiscal adjustment if Fiscal impulse (\% of GDP) is less than - 1.5

- $\quad$ strong fiscal stimuli if Fiscal impulse (\% of GDP) is larger than 1.5 
Figure 4 plots episodes of large fiscal impulse and GDP growth by country. The identification results in six episodes of fiscal adjustment and six episodes of fiscal stimuli. The longest episode persisted for 2 years (fiscal stimuli in Poland during 2008-2009 and fiscal adjustment in South Africa during 2005-2006). Many fiscal stimuli episodes occurred during the 2007-2010 global financial crisis. The time path of GDP growth suggests some association with the fiscal episodes of stimuli (positive) and adjustment (negative) in the sample period.

\section{Figure 4: Strong Fiscal Impulses and Gross Domestic Product Growth}

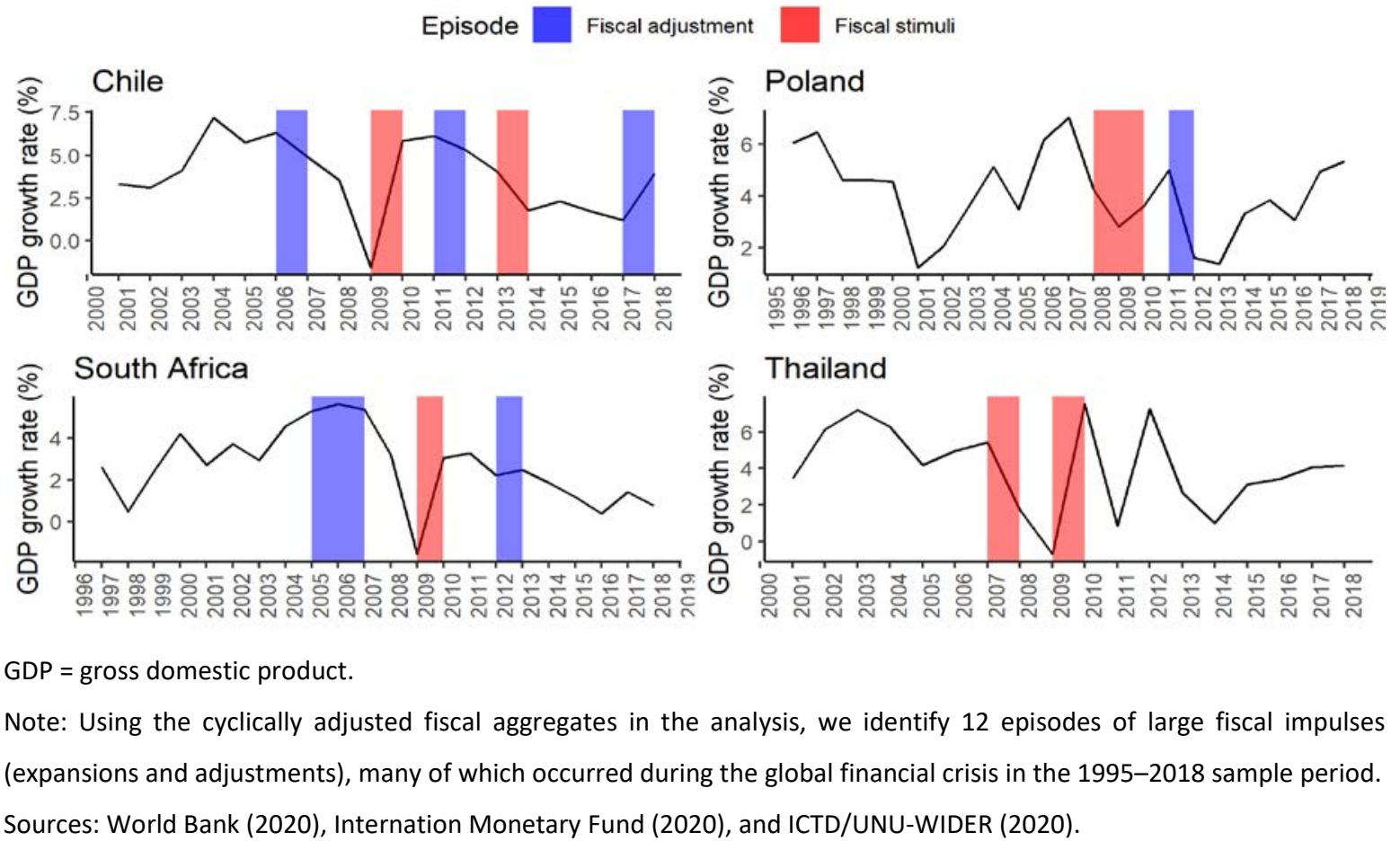

\section{B. Fiscal Episodes, Gross Domestic Product Growth, and Development Outcomes}

For our baseline estimation, we conduct fixed effects regressions on the four sample countries. First, we examine the association between GDP growth and large fiscal stimuli/adjustment changes across the years using the following equations:

$$
\begin{aligned}
& \text { GDP growth }_{i t}=\varphi_{0}+\varphi_{1} \text { Fiscal Episode }_{i t-1}+u_{i t} \\
& \text { Fiscal Episode }_{i t}=\delta_{0}+\delta_{1} G D P \text { growt }_{i t+1}+\mu_{i t} \\
& \text { Fiscal Episode }_{i t}=\gamma_{0}+\gamma_{1} \text { GDP growth } \\
& i t-1
\end{aligned}
$$


Table 1 reports the estimates of equation (3) in column (1) and equation (4) in column (2), focusing here on the statistically significant coefficients. ${ }^{2}$ We find a positive association between current GDP growth and lagged fiscal stimuli (column (1)) and between current fiscal stimuli and lead GDP growth (column (2)). While these findings do not pin down causality, they suggest that GDP growth tends to follow fiscal stimuli episodes. There is no association between lagged GDP growth and fiscal adjustment (equation (5)).

Table 1: Large Fiscal Impulses and Gross Domestic Product growth

(1) (2)

GDP Growth Fiscal Stimulit $_{t}$

Fiscal stimulit-1 $\quad 0.398^{*}$

GDP growth $_{\mathrm{t}+1} \quad 0.009 *$

(0.003)

$\begin{array}{lcc}\text { Observations } & 81 & 81 \\ \text { p-value } & 0.054 & 0.058 \\ \text { R-squared (within) } & 0.004 & 0.004\end{array}$

GDP = gross domestic product.

Notes:

1. Fixed-effects estimation with country-fixed effects included. Robust standard errors in parentheses. ***, **, and *: $1 \%$, $5 \%$, and $10 \%$ levels of significance.

2. GDP growth followed fiscal expansions. There was no association between growth rates and fiscal adjustments.

Source: Authors calculation.

Next, we look at the associations of development outcomes, GDP growth, and the interaction between GDP growth and fiscal impulses (i.e., episodes of fiscal stimuli and adjustment).

2 Full estimations are in Appendix Table A2. 
$S D G_{i t}=\beta_{0}+\beta_{1} G D P$ growth $_{i t}+\beta_{2}$ Fiscal Episode $_{i t}+\beta_{3}\left(G D P\right.$ growth $_{i t} *$ Fiscal Episode $\left._{i t}\right)+\vartheta_{i t}$

We regress equation (6) using both the fiscal stimuli and the fiscal adjustment, one at a time. The total effect of large fiscal impulses on SDGs are thus $\left(\widehat{\beta_{2}}+\widehat{\beta_{3}} * G D P\right.$ growth $)$. Similarly, the total effect of GDP growth on SDGs are $\left(\widehat{\beta_{1}}+\widehat{\beta_{3}} *\right.$ Fiscal Episode $) ;$ where $\widehat{\beta_{1}}, \widehat{\beta_{2}}$, and $\widehat{\beta_{3}}$ are estimated coefficients in regression (6). Having estimated equation (6) on all 17 SDG indicators, Tables 2 and 3 report the results, focusing on the development outcomes with statistically significant estimates. ${ }^{3}$

Table 2: Fiscal Stimuli, Growth, and Development Outcomes

\begin{tabular}{|c|c|c|c|c|}
\hline & (1) & (2) & (3) & (4) \\
\hline & Poverty & Mortalityt & Pollution $_{t}$ & Displacement $_{t}$ \\
\hline \multirow[t]{2}{*}{ GDP growth } & $1.822^{*}$ & $0.239 *$ & $0.387^{*}$ & 0.009 \\
\hline & $(0.589)$ & $(0.077)$ & (0.137) & $(0.024)$ \\
\hline \multirow[t]{2}{*}{ Fiscal stimulit } & $6.786 * *$ & 0.749 & $2.477 * *$ & $-0.247^{*}$ \\
\hline & (1.910) & $(0.386)$ & $(0.601)$ & $(0.091)$ \\
\hline Fiscal stimuli $\mathrm{x}$ & -2.055 & $-0.248^{*}$ & -0.297 & -0.045 \\
\hline GDP growth rate ${ }_{t}$ & (1.114) & $(0.084)$ & $(0.228)$ & $(0.024)$ \\
\hline Observations & 60 & 66 & 77 & 42 \\
\hline$p$-value & 0.042 & 0.019 & 0.053 & 0.000 \\
\hline R-squared (within) & 0.189 & 0.100 & 0.202 & 0.040 \\
\hline
\end{tabular}

$\mathrm{GDP}=$ gross domestic product.

Notes:

1. Fixed-effects estimation with country-fixed effects included. Robust standard errors in parentheses. ***, **, and*: $1 \%, 5 \%$, and $10 \%$ levels of significance.

2. The linkages of fiscal expansions and sustainable development outcomes differed between the long-term objectives/persistent issues (i.e., poverty, health, pollution) and the short-term objectives/urgent issues (i.e., disasters). Fiscal expansions reduced the negative trade-off between GDP growth and some development indicators, e.g., pollution and poorhealth mortalities associating with economic growth. Source: Authors calculation.

3 Full estimations for 17 SDGs are in Appendix Tables A3-A4. 
From Table 2, the current GDP growth is positively associated with current poverty headcount ratio, mortality ratio (CVD, cancer, diabetes, CRD for the people aged 30-70), and PM2.5 air pollution. This finding implies the trade-off between GDP growth and these sustainable development goals in the country sample. Current fiscal stimuli episodes are positively associated with the current poverty headcount ratio and PM2.5 air pollution and are negatively associated with the number of newly displaced people related to disasters. This finding suggests the impacts of fiscal stimuli on sustainable development goals differ between the long-term/persistent targets (poverty, health, pollution) and the short-term/pressing issues (disasters). Higher growth associated with the fiscal stimuli is negatively associated with the mortality rate from poor health conditions. Given the association between current GDP growth and lagged fiscal stimuli (Table 1), this finding implies that fiscal stimuli help mitigate the trade-off between GDP growth and some SDG outcomes.

Table 3: Fiscal Adjustment, Growth, and Development Outcomes

\begin{tabular}{|c|c|c|c|c|c|c|}
\hline & (1) & (2) & (3) & (4) & (5) & (6) \\
\hline & Poverty & Mortality & Sanitation & Fuel-Tech & Non-Education & Broadband \\
\hline \multirow[t]{2}{*}{ GDP growth rate $t$} & $1.071 * *$ & $0.194 * *$ & -0.558 & -0.677 & -0.093 & $-0.462 *$ \\
\hline & $(0.257)$ & $(0.044)$ & $(0.309)$ & $(0.509)$ & $(0.182)$ & $(0.150)$ \\
\hline \multirow[t]{2}{*}{ Fiscal adjustment $_{t}$} & $-12.014 * *$ & -0.819 & $3.261 * *$ & $9.805^{* * *}$ & -3.060 & 5.485 \\
\hline & (3.055) & $(0.506)$ & (0.933) & (1.591) & $(1.500)$ & $(2.754)$ \\
\hline Fiscal adjustment $t_{t} x$ & $2.294^{* * *}$ & 0.054 & -0.465 & $-1.644^{* *}$ & $0.640 *$ & -0.641 \\
\hline GDP growth rate $t$ & $(0.211)$ & $(0.056)$ & $(0.248)$ & $(0.460)$ & $(0.230)$ & $(0.361)$ \\
\hline Observations & 60 & 66 & 70 & 66 & 62 & 71 \\
\hline$p$-value & 0.000 & 0.000 & 0.013 & 0.000 & 0.000 & 0.011 \\
\hline R-squared (within) & 0.170 & 0.089 & 0.118 & 0.115 & 0.008 & 0.056 \\
\hline
\end{tabular}

GDP $=$ gross domestic product. Notes:

1. Fixed-effects estimation with country-fixed effects included. Robust standard errors in parentheses. ***, **, and *: $1 \%$, $5 \%$, and $10 \%$ levels of significance.

2. Lowered poverty headcounts and improved sanitation, and cleaner technology followed fiscal adjustments. However, there was some trade-off between GDP growth and such association in the sample.

Source: Authors calculation.

From Table 3, the GDP growth rate is positively associated with the poverty headcount ratio and mortality from CVD, cancer, diabetes, or CRD for the people aged 30-70. However, GDP growth is 
negatively correlated with broadband subscriptions. Fiscal adjustment episodes are negatively associated with the poverty headcount ratio and are positively associated with access to basic sanitation services and clean fuels and cooking technologies. The association between fiscal adjustment episodes and poverty headcount ratio declines as GDP grows: the threshold of GDP growth is $5.24 \%$ [12.014/2.294], above which the effect of fiscal adjustment dissipated. The GDP growth coinciding with fiscal adjustment episodes is negatively associated with access to clean fuels and technologies for cooking (the GDP growth threshold is 5.96\%). It is positively associated with the young population share, not in education, employment, or training.

We also adjust equation (6) by entering lead (period $t+1$ ) and lagged (period $t$-1) variables of GDP growth, large fiscal impulses, and the interaction between GDP growth and large fiscal impulses as regressors. Appendix Tables $A 5$ and $A 6$ report detailed results using lead explanatory variables and Tables A7 and A8 for lagged variables. The extended results are largely supportive to the baseline findings from regression (6) for the four sample countries: (i) there is the trade-off between (lagged, current, and lead) GDP growth rate and the development goals; (ii) the fiscal adjustment (stimuli) episodes are favorable (unfavorable) to development goals; and (iii) the GDP growth coinciding with fiscal adjustment (stimuli) episodes deteriorates (improves) the development goals. These findings are not applicable for all SDGs, however.

\section{Large Fiscal Impulses and Tax-Spending Components}

We further test whether fiscal episodes are associated with any components of the fiscal trends by estimating the following equation of fiscal episode at time $t$ on the fiscal components at time $t+1$ and $t$ 1:

$$
\begin{aligned}
& \text { Fiscal episode }_{i t}=\mu_{0}+\mu_{1} \text { Tax (or Expense) } \text { components }_{i t+1}+\varepsilon_{i t} \\
& \text { Fiscal episode }_{i t}=\theta_{0}+\theta_{1} \text { Tax (or Expense) } \text { components }_{i t-1}+\epsilon_{i t}
\end{aligned}
$$

We estimate equations (7) and (8) separately for fiscal stimuli and fiscal adjustment episodes. The independent variables include cyclically adjusted tax (or expense) components as a share of GDP. We report the significant findings on the tax components' estimates in Table 4 and the expense elements in 
Table $5 .{ }^{4}$ Note that entering each (lead and lagged) component as an explanatory variable at a time does not alter the significant findings below. The results are available upon request.

Table 4: Large Fiscal Impulses and Tax Components

\begin{tabular}{|c|c|c|c|c|c|c|}
\hline & \multicolumn{4}{|c|}{ Fiscal Stimuli ${ }_{t}$} & \multicolumn{2}{|c|}{ Fiscal Adjustment $_{t}$} \\
\hline & (1) & (2) & (3) & (4) & (5) & (6) \\
\hline Personal income tax $x_{t+1}$ & $\begin{array}{c}0.058 \\
(0.049)\end{array}$ & & & & & \\
\hline Corporate income tax $\mathrm{t}_{\mathrm{t}+1}$ & $\begin{array}{c}0.003 \\
(0.056)\end{array}$ & & & & & \\
\hline Other direct taxes $s_{t+1}$ & $\begin{array}{l}-0.242 \\
(0.220)\end{array}$ & & & & & \\
\hline Direct taxes $_{t+1}$ & & $\begin{array}{c}0.025 \\
(0.050)\end{array}$ & & & & \\
\hline Indirect taxes $\mathrm{t}_{t+1}$ & $\begin{array}{l}-0.077 \\
(0.055)\end{array}$ & $\begin{array}{l}-0.072 \\
(0.049)\end{array}$ & & & & \\
\hline Social contributions $\mathrm{t}_{\mathrm{t}+1}$ & $\begin{array}{c}-0.218^{* *} \\
(0.066)\end{array}$ & $\begin{array}{c}-0.232^{* *} \\
(0.060)\end{array}$ & & & & \\
\hline Personal income tax $\mathrm{x}_{\mathrm{t}-1}$ & & & $\begin{array}{c}0.019 \\
(0.037)\end{array}$ & & $\begin{array}{l}-0.054 \\
(0.030)\end{array}$ & \\
\hline Corporate income tax $\mathrm{t}_{\mathrm{t}-1}$ & & & $\begin{array}{c}0.095 * * * \\
(0.007)\end{array}$ & & $\begin{array}{l}-0.039 \\
(0.036)\end{array}$ & \\
\hline Other direct taxes $\mathrm{t}_{-1}$ & & & $\begin{array}{c}-0.225^{* * *} \\
(0.027)\end{array}$ & & $\begin{array}{c}-0.632 * * * \\
(0.086)\end{array}$ & \\
\hline Direct taxes ${ }_{t-1}$ & & & & $\begin{array}{c}0.067^{* *} \\
(0.018)\end{array}$ & & $\begin{array}{l}-0.043 \\
(0.045)\end{array}$ \\
\hline Indirect taxes ${ }_{t-1}$ & & & $\begin{array}{c}0.031 \\
(0.092)\end{array}$ & $\begin{array}{c}0.015 \\
(0.076)\end{array}$ & $\begin{array}{l}-0.007 \\
(0.060)\end{array}$ & $\begin{array}{l}-0.014 \\
(0.064)\end{array}$ \\
\hline Social contributions $\mathrm{t}_{\mathrm{t}-1}$ & & & $\begin{array}{c}-0.089 * * \\
(0.020)\end{array}$ & $\begin{array}{c}-0.087^{* *} \\
(0.017)\end{array}$ & $\begin{array}{c}-0.103 * \\
(0.037)\end{array}$ & $\begin{array}{c}-0.135^{* *} \\
(0.035)\end{array}$ \\
\hline
\end{tabular}

\footnotetext{
${ }^{4}$ Full estimations are in Appendix Tables A9-A10.
} 


\begin{tabular}{lcccc|cc} 
Observations & 77 & 77 & 81 & 81 & 81 & 81 \\
p-value & $\cdot$ & 0.010 &. & 0.000 &. & 0.099 \\
R-squared (within) & 0.142 & 0.124 & 0.137 & 0.097 & 0.124 & 0.059 \\
\hline
\end{tabular}

\section{Notes:}

1. Explanatory variables are cyclically adjusted. Fixed effects estimation with country-fixed effects included. Robust standard errors in parentheses. ${ }^{* * *},{ }^{* *}$, and $*: 1 \%, 5 \%$, and $10 \%$ levels of significance.

2. The time paths of fiscal aggregates differ across countries. Fiscal expansions followed an increase in direct taxes, especially corporate tax, and a decline in social contributions. Fiscal adjustments followed a decline in other direct taxes and social contributions.

Source: Authors calculation.

We note that tax components, including personal income tax, corporate income tax, indirect taxes, and social contributions, are cyclically adjusted but not other direct taxes; all are in GDP percentage.

Columns (1)-(4) in Table 4 show that fiscal stimuli episodes (period $t$ ) are negatively associated with lead and lagged social contributions (periods $t+1, t-1$ ), suggesting that the episodes of fiscal stimuli are associated with trends in the social contributions. Fiscal stimuli episodes are positively associated with lagged corporate income taxes and negatively associated with lagged other taxes, both of which were not subject to these tax components' trend.

As an additional test, we aggregate cyclically adjusted direct taxes and re-estimate the equations (7)(8). Specifically,

Cyclically adjusted direct tax (\% of GDP) = Cyclically adjusted PIT + Cyclically adjusted CIT + Other.

Columns (2) and (4) of Table 4 provide the results, further supporting the negative association between fiscal stimuli and social contributions. Fiscal stimuli episodes are also positively associated with lagged direct taxes.

For the fiscal adjustments, we find that they are negatively associated with lagged other direct taxes (column (5) of Table 4) and lagged social contributions (column (6) of Table 4). Fiscal adjustments are not associated with any lead tax components. 
Table 5: Large Fiscal Impulses and Expense Components

\begin{tabular}{|c|c|c|c|}
\hline & \multicolumn{3}{|c|}{ Fiscal Adjustment $_{t}$} \\
\hline & (1) & (2) & (3) \\
\hline \multirow[t]{2}{*}{ Wage $_{t+1}$} & 0.020 & & \\
\hline & $(0.031)$ & & \\
\hline \multirow[t]{2}{*}{ Non-wage $_{t+1}$} & -0.059 & & \\
\hline & $(0.056)$ & & \\
\hline \multirow[t]{2}{*}{ Gov. consumption expenditure $\mathrm{t}_{\mathrm{t}+1}$} & & $-0.016^{*}$ & \\
\hline & & $(0.006)$ & \\
\hline \multirow[t]{2}{*}{ Subsidies ${ }_{t+1}$} & -0.070 & -0.083 & \\
\hline & $(0.060)$ & $(0.048)$ & \\
\hline \multirow[t]{2}{*}{ Transfer $_{t+1}$} & $-0.060 *$ & $-0.073 * *$ & \\
\hline & $(0.022)$ & $(0.015)$ & \\
\hline \multirow[t]{2}{*}{ Wage $_{t-1}$} & & & $0.042 *$ \\
\hline & & & $(0.016)$ \\
\hline \multirow[t]{2}{*}{ Non-wage $t-1$} & & & 0.003 \\
\hline & & & $(0.017)$ \\
\hline \multirow[t]{2}{*}{ Subsidies $t-1$} & & & -0.009 \\
\hline & & & $(0.025)$ \\
\hline \multirow[t]{2}{*}{ Transfer ${ }_{t-1}$} & & & -0.071 \\
\hline & & & $(0.042)$ \\
\hline Observations & 77 & 77 & 81 \\
\hline$p$-value & . & 0.061 & . \\
\hline R-squared (within) & 0.084 & 0.074 & 0.029 \\
\hline
\end{tabular}

Gov. = government.

Notes:

1. Explanatory variables are cyclically adjusted. Fixed effects estimation with country-fixed effects included. Robust standard errors in parentheses. $* * *, * *$, and $*$ : $1 \%, 5 \%$, and $10 \%$ levels of significance. 
2. Fiscal adjustments followed an increase in wage bills and preceded a decline in government consumption expenditure and transfers.

Source: Authors calculation.

Table 5 reports the significant estimates of equations (7) and (8) for fiscal adjustment episodes and expense components. Fiscal stimuli episodes are not associated with any (lead and lagged) expenditure components. We include four expense components, including wage bills, non-wage bills, subsidies expenditure, and cyclically adjusted transfer (all as a share of GDP). Columns (1) and (3) of Table 5 show that fiscal adjustment episodes (period $t$ ) are negatively associated with lead transfer expenses (period $t+1$ ) but not with the lagged transfer expense (period $t-1$ ). Aggregating government consumption expenditure:

Government consumption expenditure (\% of GDP) = Wage + Non-wage, shown in column (2), we find that the lead transfer component (period $t+1$ ) is still negatively associated with current fiscal adjustment episodes (period $t$ ). Besides, lead government consumption expenditure is negatively associated with current fiscal adjustment episodes. We also find that current fiscal adjustment episodes (period $t$ ) are positively associated with the lagged expense on wage bills (period $t-1$ ), shown in column (3).

We also test whether current tax or expense components (period $t$ ) are associated with lagged fiscal episodes (period $t-1$ ) by estimating the following equation:

$$
\text { Tax (or Expense) } \text { components }_{i t}=\pi_{0}+\pi_{1} \text { Fiscal Episode }_{i t-1}+\epsilon_{i t}
$$

As shown in Table 6 column (1), the other direct taxes (period $t$ ) are negatively associated with lagged fiscal stimuli (period $t-1$ ); in contrast, wage bills are positively associated with the lagged fiscal stimuli (column (2)). We also find that cyclically adjusted transfer expense is negatively associated with the lagged fiscal adjustment (column (3)). Appendix Table A11 provides full estimation results across tax and expense components. 
Table 6: Tax/Expense Components and Fiscal Stimuli/Adjustment

\begin{tabular}{lccc}
\hline & $\begin{array}{c}\text { (1) } \\
\text { Others }\end{array}$ & $\begin{array}{c}\text { (2) } \\
\text { Waget }_{\mathbf{t}}\end{array}$ & $\begin{array}{c}\text { (3) } \\
\text { Transfer }_{\mathbf{t}}\end{array}$ \\
\hline Fiscal stimulit-1 & $-0.051^{*}$ & $0.512^{*}$ & \\
& $(0.016)$ & $(0.183)$ & \\
Fiscal adjustment & & & $-0.535^{*}$ \\
& & & $(0.195)$ \\
& & & \\
Observations & & & 77 \\
p-value & 77 & 77 & 0.071 \\
R-squared (within) & 0.016 & 0.037 & 0.049
\end{tabular}

Notes:

1. Transfer expense is cyclically adjusted. Fixed effects estimation with countryfixed effects included. Robust standard errors in parentheses. ${ }^{* * *},{ }^{* *}$, and ${ }^{*}: 1 \%$, $5 \%$, and $10 \%$ levels of significance.

2. A decline in other direct taxes and an increase in the wage bills followed fiscal expansions, while a decline in transfers followed fiscal adjustments.

Source: Authors calculation. 


\section{CONCLUSION}

We find stylized patterns on the linkages between large fiscal episodes and sustainable development outcomes in selected developing countries. The findings suggest that domestic resource mobilization should consider differences in tax base and expenditure components and their linkages with the sustainable development outcomes. By focusing on country studies of Chile, Poland, South Africa, and Thailand, we have gained insights into distinct country challenges. Poland, for instance, benefited significantly from European Union transfers and the proximity of Germany. This specific circumstance suggests that Poland's experience is less transferable to other non-European Union countries.

Future studies may consider the case of federal countries controlling for provincial-state heterogeneity, i.e., provincial states in a federal system in larger states (India, the Philippines, Indonesia, among others. This approach will require information on the inclusive growth and tax mobilization at the provincial state level and the transfer of tax revenue and grants between the provincial and the federal levels. The quality of the data will determine the feasibility and success of such a study. Extensions may incorporate public debt evolution, examining the paths of fiscal components and development outcomes in times of fiscal stress vis-à-vis in normal times in the sample countries. 


\section{APPENDIX}

Variables description

Expense components

- Wage: General government expenditure on wage bill (\% of GDP), i.e., compensation of employees.

- $\quad$ Non-wage: General government expenditure on non-wage bills (\% of GDP), i.e., use of goods and services.

- Investment: General government expenditure on fixed capital (\% of GDP), i.e., consumption of fixed capital.

- $\quad$ Subsidies: General government subsidies to firms (\% of GDP).

- $\quad$ Transfer: General government expenditure on social benefits (\% of GDP).

Tax revenue components

- PIT: Total income, capital gains, and profit taxes on individuals (\% of GDP), exclusive of resource revenues.

- $\quad$ CIT: Total non-resource income and profits taxes on corporations (\% of GDP).

- $\quad$ Other: Other direct taxes, including taxes on payroll and workforce and taxes on property (\% of GDP).

- INDT: Total non-resource indirect taxes, including taxes on goods and services, taxes on international trade, and other taxes (\% of GDP).

- $\quad$ SSC: Total social contributions (\% of GDP).

Unemployment rate: The unemployed share of the total labor force (modeled International Labour Organization estimate).

\section{Sustainable Development Goals}

- $\quad$ Poverty: Poverty headcount ratio at national poverty lines (\% of the population).

- $\quad$ Undernourishment: Population below minimum level of dietary energy consumption (\% of the population).

- $\quad$ Mortality: Percent of 30-year-old-people who would die before their 70th birthday from cardiovascular disease, cancer, diabetes, or chronic respiratory disease.

- $\quad$ Enrollment: School enrollment at pre-primary education level (\% gross).

- Women power: Proportion of seats held by women in national parliaments (\%).

- $\quad$ Sanitation: People using at least basic sanitation services (\% of the population). These services include flush/pour flush to piped sewer systems, septic tanks or pit latrines, ventilated improved pit latrines, compositing toilets or pit latrines with slabs.

- $\quad$ Fuel-tech: The population primarily use clean cooking fuels and technologies for cooking (\% of the population). 
- $\quad$ Non-education: Young people who are not in education, employment, or training to the population of the corresponding age group: youth (ages 15-24); persons ages 15-29; or both age groups (\% of the youth population).

- $\quad$ Broadband: Fixed broadband subscriptions (per 100 people).

- $\quad$ Bottom consumption: Survey mean consumption or income per capita, Bottom $40 \%$ of the population (2011 purchasing power parity (PPP) \$ per day).

- $\quad$ Pollution: PM2.5 air pollution mean annual exposure (micrograms per cubic meter).

- $\quad$ Carbon dioxide damage: Cost of damage because of carbon dioxide emissions from fossil fuel use and cement manufacture (\% of gross national income).

- $\quad$ Displacement: Internally displaced persons, new displacement associated with disasters (million cases).

- $\quad$ Marine: Marine protected areas (\% of territorial waters).

- $\quad$ Terrestrial: Terrestrial protected areas (\% of total land area).

- $\quad$ Bribery: Percentage of firms experiencing at least one bribe payment request across six public transactions dealing with utility access, permits, licenses, and taxes.

- Remittances: Personal remittances received, including personal transfers and compensation of employees (\% of GDP). 


\section{REFERENCES}

Alesina, A. and S. Ardagna. 2010. Large changes in fiscal policy: taxes versus spending. Tax Policy and the Economy. 24(1), pp. 35-68.

Alesina, A. and R. Perotti. 1995. Fiscal expansions and adjustments in OECD countries. Economic Policy. 10(21), pp. 205-248.

Blanchard, O. 1993. Suggestion for a new set of fiscal indicators. OECD Working Paper. Organisation for Economic Co-operation and Development (OECD).

ICTD/UNU-WIDER. $2020 . \quad$ Government Revenue Dataset. https://www.wider.unu.edu/project/government-revenue-dataset.

Internation Monetary Fund. (2020). Government Financial Statistics. https://data.imf.org/?sk=A0867067-D23C-4EBC-AD23-D3B015045405.

The Growth Lab at Harvard University. (2019). Growth Projections and Complexity Rankings, V2. https://doi.org/10.7910/dvn/xtaqmc.

World Bank. (2020). World Development Indicators. https://databank.worldbank.org/source/worlddevelopment-indicators 
Table A1: Statistics Description of Fiscal Impulse/Stimuli/Adjustment by Country

Fiscal impulse

\begin{tabular}{lccccc}
\hline Country & Observations & Mean & $\begin{array}{c}\text { Standard } \\
\text { Deviation }\end{array}$ & Min & Max \\
\hline Chile & 18 & -0.188 & 1.267 & -2.300 & 2.568 \\
Poland & 23 & 0.081 & 1.120 & -2.548 & 2.729 \\
South Africa & 22 & -0.003 & 1.560 & -1.968 & 4.836 \\
Thailand & 18 & 0.249 & 1.309 & -1.385 & 3.353 \\
\hline
\end{tabular}

Table A1. (continued)

Fiscal stimuli

\begin{tabular}{lccccc}
\hline Country & Observations & Mean & $\begin{array}{c}\text { Standard } \\
\text { Deviation }\end{array}$ & Min & Max \\
\hline Chile & 18 & 0.111 & 0.323 & 0 & 1 \\
Poland & 23 & 0.130 & 0.344 & 0 & 1 \\
South Africa & 22 & 0.045 & 0.213 & 0 & 1 \\
Thailand & 18 & 0.111 & 0.323 & 0 & 1 \\
\hline
\end{tabular}

Table A1. (continued)

Fiscal adjustment

\begin{tabular}{lccccc}
\hline Country & Observations & Mean & $\begin{array}{c}\text { Standard } \\
\text { Deviation }\end{array}$ & Min & Max \\
\hline Chile & 18 & 0.167 & 0.383 & 0 & 1 \\
Poland & 23 & 0.043 & 0.209 & 0 & 1 \\
South Africa & 22 & 0.227 & 0.429 & 0 & 1 \\
Thailand & 18 & 0.000 & 0.000 & 0 & 1 \\
\hline
\end{tabular}

Max = maximum, Min = minimum.

Note: Data to compute fiscal impulse/stimuli/adjustment episodes are Chile 2000-2018, Poland 1995-2018, South Africa 1996-2018, and Thailand 2000-2018. Fiscal impulse's unit is the percentage of gross domestic product. Fiscal stimuli and Fiscal adjustment are binary variables.

Source: Authors calculation. 
Table A2: Fiscal Impulses and Gross Domestic Product Growth

\begin{tabular}{|c|c|c|c|c|c|c|}
\hline & $\begin{array}{c}\text { (1) } \\
\text { GDP growth }\end{array}$ & $\begin{array}{c}\text { (2) } \\
\text { GDP growth }\end{array}$ & $\begin{array}{c}\text { (3) } \\
\text { Fiscal stimuli }\end{array}$ & $\begin{array}{c}\text { (4) } \\
\text { Fiscal stimuli }\end{array}$ & $\begin{array}{c}\text { (5) } \\
\text { Fiscal adjustment }{ }_{\mathrm{t}}\end{array}$ & $\begin{array}{c}\text { (6) } \\
\text { Fiscal adjustment }\end{array}$ \\
\hline Fiscal stimuli $\mathrm{i}_{\mathrm{t}-1}$ & $\begin{array}{l}0.398^{*} \\
(0.129)\end{array}$ & & & & & \\
\hline Fiscal adjustment $_{\mathrm{t}-1}$ & & $\begin{array}{c}0.594 \\
(0.579)\end{array}$ & & & & \\
\hline GDP growth gr-1 & & & $\begin{array}{c}0.019 \\
(0.021)\end{array}$ & & $\begin{array}{l}0.023 \\
(0.020)\end{array}$ & \\
\hline GDP growth $_{t+1}$ & & & & $\begin{array}{l}0.009 * \\
(0.003)\end{array}$ & & $\begin{array}{c}0.014 \\
(0.018)\end{array}$ \\
\hline Observations & 81 & 81 & 81 & 81 & 81 & 81 \\
\hline$p$-value & 0.054 & 0.380 & 0.446 & 0.058 & 0.345 & 0.486 \\
\hline R-squared (within) & 0.004 & 0.008 & 0.015 & 0.004 & 0.022 & 0.008 \\
\hline
\end{tabular}

$\mathrm{GDP}=$ gross domestic product.

Note: Fixed-effects estimation with country-fixed effects included. Robust standard errors in parentheses. ${ }^{* * *}, * *$, and $*: 1 \%, 5 \%$, and $10 \%$ levels of significance.

Source: Authors calculation. 
Table A3: Fiscal Stimuli, Growth, and Development Outcomes

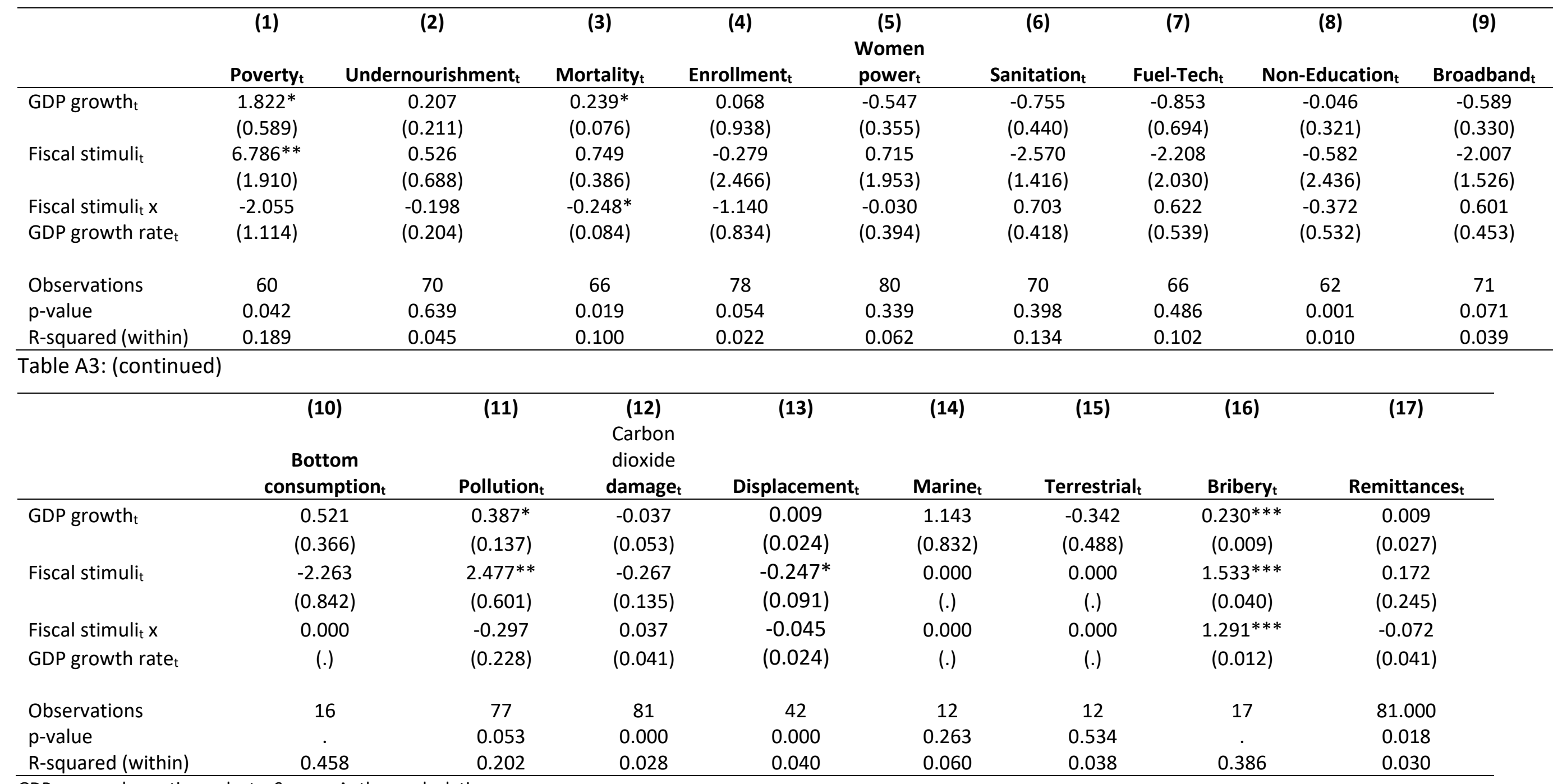

GDP = gross domestic product. Source: Authors calculation.

Note: Fixed-effects estimation with country-fixed effects included. Robust standard errors in parentheses. ${ }^{* * *}$, **, and *: $1 \%, 5 \%$, and $10 \%$ levels of significance. 
Table A4: Fiscal Adjustment, Growth, and Development Outcomes

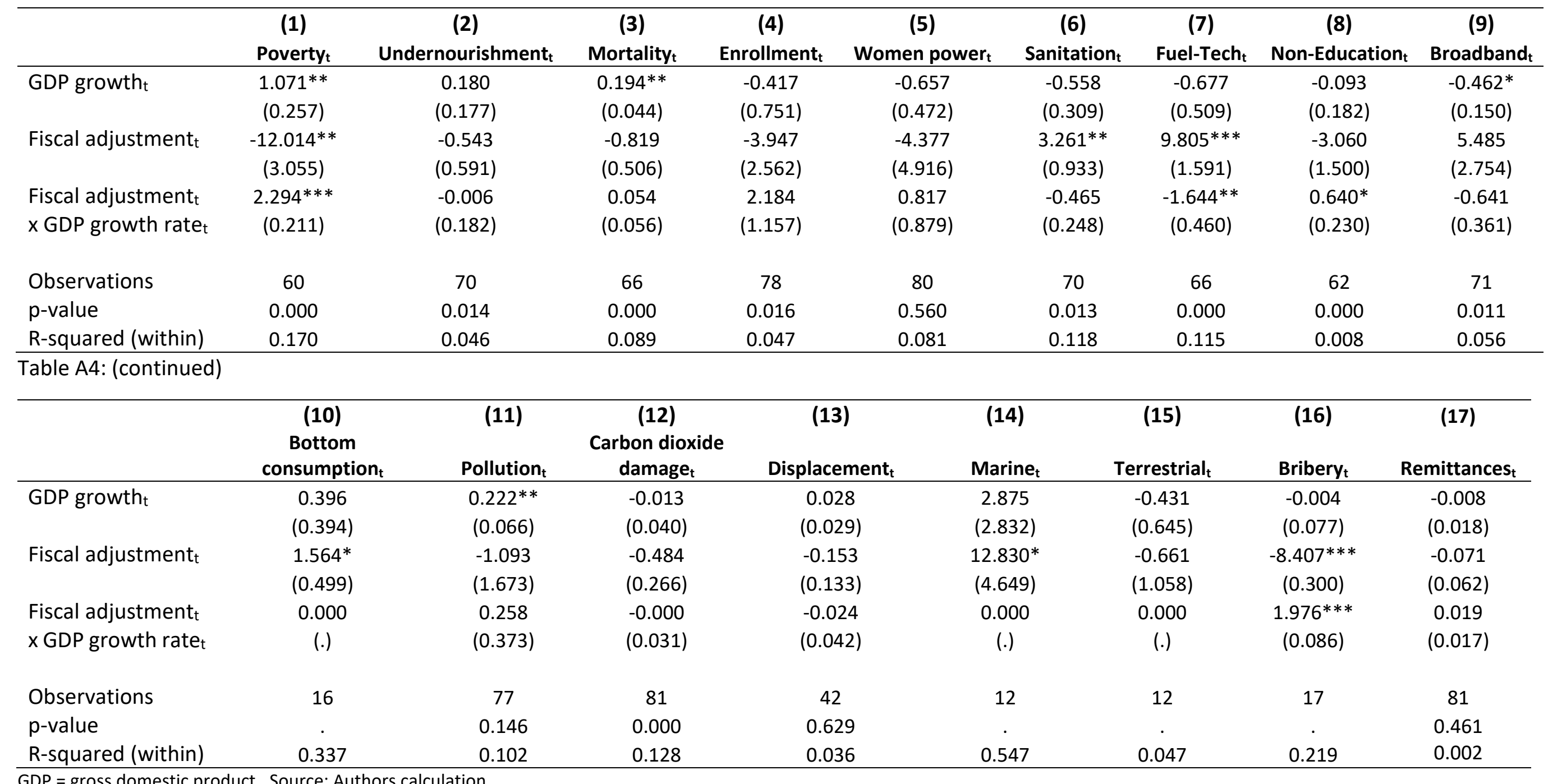

GDP = gross domestic product. Source: Authors calculation.

Note: Fixed-effects estimation with country-fixed effects included. Robust standard errors in parentheses. ${ }^{* * *}, * *$, and ${ }^{*}: 1 \%, 5 \%$, and $10 \%$ levels of significance. 
Table A5: Future Fiscal Stimuli, Growth, and Development Outcomes

\begin{tabular}{|c|c|c|c|c|c|c|c|c|c|}
\hline & $\begin{array}{c}\text { (1) } \\
\text { Poverty } t\end{array}$ & $\begin{array}{c}\text { (2) } \\
\text { Undernourishment }_{\mathrm{t}}\end{array}$ & $\begin{array}{c}\text { (3) } \\
\text { Mortalityt }\end{array}$ & $\begin{array}{c}\text { (4) } \\
\text { Enrollment }_{t}\end{array}$ & $\begin{array}{c}\text { (5) } \\
\text { Women } \text { power }_{t}\end{array}$ & $\begin{array}{c}(6) \\
\text { Sanitation }_{t}\end{array}$ & $\begin{array}{c}\text { (7) } \\
\text { Fuel-Tech }\end{array}$ & $\begin{array}{c}\text { (8) } \\
\text { Non-Education }_{t}\end{array}$ & $\begin{array}{c}\text { (9) } \\
\text { Broadband } d_{t}\end{array}$ \\
\hline GDP growth ${ }_{t+1}$ & 1.953* & 0.237 & 0.217 & -0.160 & -0.467 & -0.730 & -0.914 & -0.223 & $-0.901 * *$ \\
\hline & $(0.626)$ & $(0.252)$ & $(0.100)$ & (0.598) & (0.331) & (0.498) & $(0.712)$ & (0.668) & $(0.207)$ \\
\hline Fiscal stimuli $\mathrm{t}_{\mathrm{t}+1}$ & $\begin{array}{c}8.796 * * \\
(2.307)\end{array}$ & $\begin{array}{c}0.570 \\
(0.749)\end{array}$ & $\begin{array}{c}0.827 \\
(0.452)\end{array}$ & $\begin{array}{c}0.700 \\
(3.779)\end{array}$ & $\begin{array}{l}-2.073 \\
(2.076)\end{array}$ & $\begin{array}{l}-2.995 \\
(1.731)\end{array}$ & $\begin{array}{l}-2.971 \\
(2.324)\end{array}$ & $\begin{array}{l}-0.931 \\
(2.505)\end{array}$ & $\begin{array}{c}-3.752 * * * \\
(0.611)\end{array}$ \\
\hline $\begin{array}{l}\text { Fiscal stimuli }{ }_{t+1} \mathrm{X} \\
\text { GDP growth rate } \mathrm{t}_{\mathrm{t}+1}\end{array}$ & $\begin{array}{c}-2.379 * \\
(0.950)\end{array}$ & $\begin{array}{l}-0.188 \\
(0.214)\end{array}$ & $\begin{array}{l}-0.199 \\
(0.098)\end{array}$ & $\begin{array}{c}0.103 \\
(1.053)\end{array}$ & $\begin{array}{c}0.372 \\
(0.517)\end{array}$ & $\begin{array}{c}0.689 \\
(0.499)\end{array}$ & $\begin{array}{c}0.795 \\
(0.608)\end{array}$ & $\begin{array}{l}-0.290 \\
(0.622)\end{array}$ & $\begin{array}{l}0.854 \\
(0.454)\end{array}$ \\
\hline Observations & 60 & 72 & 68 & 81 & 78 & 72 & 68 & 59 & 68 \\
\hline$p$-value & 0.013 & 0.718 & 0.000 & 0.004 & 0.151 & 0.036 & 0.670 & 0.001 & 0.001 \\
\hline R-squared (within) & 0.183 & 0.046 & 0.080 & 0.002 & 0.032 & 0.124 & 0.118 & 0.018 & 0.092 \\
\hline
\end{tabular}

Table A5: (continued)

(10)

(13)

\section{(12)}

Carbon

dioxide

Bottom consumption ${ }_{t}$

GDP growth $_{\mathrm{t}+1}$

$0.681^{*}$

(0.219)

0.000

$($.

(.)

15

0.614

$\begin{array}{cc}\text { Pollution }_{\mathbf{t}} & \text { damage }_{\mathbf{t}} \\ 0.235 & -0.003 \\ (0.132) & (0.037) \\ 1.832 * * & -0.203^{*} \\ (0.553) & (0.084) \\ -0.101 & 0.033 \\ (0.199) & (0.025)\end{array}$

(0.199)

(0.025)

81

0.017

0.109

R-squared (within)

$81-38$

$0.034 \quad 0.000$

0.011

Displacement $_{\mathrm{t}}$

$0.053^{* *} \quad$ Marine $_{\mathrm{t}}$

$(0.015)$

$-0.094$

$(0.101)$

$-0.095^{* *}$

(0.018)

(15)

(16)

(17)

GDP = gross domestic product. Source: Authors calculation.

Note: Fixed-effects estimation with country-fixed effects included. Robust standard errors in parentheses. ${ }^{* * *}, * *$, and $*: 1 \%, 5 \%$, and $10 \%$ levels of significance. 
Table A6: Future Fiscal Adjustment, Growth, and Development Outcomes

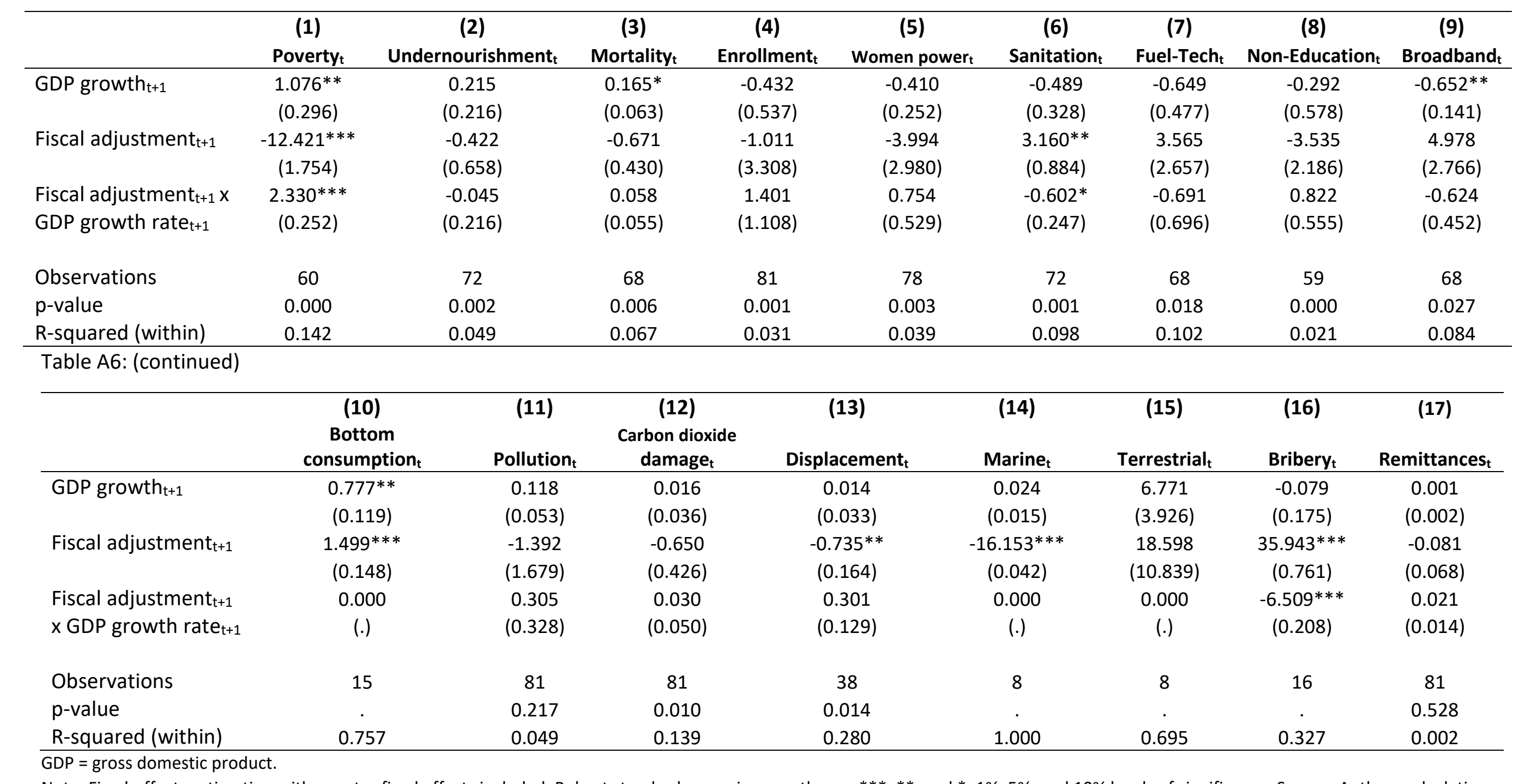

Note: Fixed-effects estimation with country-fixed effects included. Robust standard errors in parentheses. ${ }^{* * *}, * *$, and $*$ : $1 \%, 5 \%$, and $10 \%$ levels of significance. Source: Authors calculation. 
Table A7: Past Fiscal Stimuli, Growth, and Development Outcomes

\begin{tabular}{|c|c|c|c|c|c|c|c|c|c|}
\hline & $\begin{array}{c}\text { (1) } \\
\text { Poverty }\end{array}$ & $\begin{array}{c}\text { (2) } \\
\text { Undernourishment }\end{array}$ & $\begin{array}{c}\text { (3) } \\
\text { Mortality }\end{array}$ & $\begin{array}{c}\text { (4) } \\
\text { Enrollment }\end{array}$ & $\begin{array}{c}\text { (5) } \\
\text { Women power }\end{array}$ & $\begin{array}{c}\text { (6) } \\
\text { Sanitation }\end{array}$ & $\begin{array}{c}\text { (7) } \\
\text { Fuel-Tech }\end{array}$ & $\begin{array}{c}\text { (8) } \\
\text { Non-Education }_{\mathrm{t}}\end{array}$ & $\begin{array}{c}\text { (9) } \\
\text { Broadband }\end{array}$ \\
\hline \multirow[t]{2}{*}{ GDP growth t-1 } & $1.469 * *$ & 0.155 & $0.202^{*}$ & -0.123 & -0.535 & -0.674 & -0.523 & 0.822 & $-0.650 *$ \\
\hline & $(0.437)$ & (0.178) & $(0.064)$ & $(0.912)$ & (0.479) & $(0.325)$ & $(0.401)$ & $(0.627)$ & $(0.245)$ \\
\hline \multirow[t]{2}{*}{ Fiscal stimuli $\mathrm{i}_{\mathrm{t}-1}$} & $4.031 *$ & 0.276 & 0.436 & 5.767 & -0.017 & -1.754 & -0.523 & 1.676 & -1.546 \\
\hline & (1.610) & $(0.606)$ & $(0.361)$ & (7.248) & $(2.286)$ & $(0.851)$ & $(0.706)$ & (1.469) & $(1.365)$ \\
\hline Fiscal stimuli $\mathrm{t}_{\mathrm{t}-1} \mathrm{X}$ & -1.294 & -0.134 & $-0.237^{*}$ & -2.011 & -0.417 & 0.609 & 0.221 & -0.623 & 0.825 \\
\hline GDP growth rate t- 1 & (1.038) & $(0.171)$ & $(0.075)$ & (1.784) & $(0.517)$ & $(0.285)$ & $(0.228)$ & $(0.404)$ & $(0.381)$ \\
\hline Observations & 58 & 68 & 64 & 74 & 81 & 68 & 64 & 65 & 69 \\
\hline$p$-value & 0.101 & 0.537 & 0.022 & 0.171 & 0.607 & 0.345 & 0.463 & 0.002 & 0.011 \\
\hline R-squared (within) & 0.143 & 0.036 & 0.081 & 0.051 & 0.068 & 0.108 & 0.043 & 0.112 & 0.056 \\
\hline
\end{tabular}

Table A7: (continued)

\begin{tabular}{|c|c|c|c|c|c|c|c|c|}
\hline & $\begin{array}{c}\text { (10) } \\
\text { Bottom } \\
\text { consumption }_{\mathrm{t}}\end{array}$ & $\begin{array}{c}\text { (11) } \\
\text { Pollution }_{\mathrm{t}}\end{array}$ & $\begin{array}{c}\text { (12) } \\
\text { Carbon } \\
\text { dioxide } \\
\text { damage }_{\mathrm{t}}\end{array}$ & Displacement $_{t}$ & Marine $_{\mathrm{t}}$ & Terrestrial $_{\mathbf{t}}$ & Bribery $_{t}$ & Remittances \\
\hline GDP growth $_{\mathrm{t}-1}$ & $\begin{array}{l}-0.134 \\
(0.143)\end{array}$ & $\begin{array}{l}0.449 * * \\
(0.101)\end{array}$ & $\begin{array}{l}-0.056 \\
(0.043)\end{array}$ & $\begin{array}{c}0.028 \\
(0.063)\end{array}$ & $\begin{array}{l}-2.699 \\
(3.242)\end{array}$ & $\begin{array}{c}0.328 \\
(0.418)\end{array}$ & $\begin{array}{c}0.541 \\
(0.364)\end{array}$ & $\begin{array}{l}-0.006 \\
(0.024)\end{array}$ \\
\hline Fiscal stimuli $\mathrm{i}_{\mathrm{t}-1}$ & $\begin{array}{c}-0.361 \\
(0.181)\end{array}$ & $\begin{array}{l}2.821^{* *} \\
(0.605)\end{array}$ & $\begin{array}{l}-0.640 \\
(0.291)\end{array}$ & $\begin{array}{c}0.819 \\
(0.450)\end{array}$ & $\begin{array}{c}0.000 \\
(.)\end{array}$ & $\begin{array}{c}0.000 \\
(.)\end{array}$ & $\begin{array}{c}1.178 \\
(1.554)\end{array}$ & $\begin{array}{c}0.051 \\
(0.179)\end{array}$ \\
\hline $\begin{array}{l}\text { Fiscal stimuli } i_{t-1} \mathrm{x} \\
\text { GDP growth rate } \mathrm{t}_{\mathrm{t}-1}\end{array}$ & $\begin{array}{l}0.000 \\
(.)\end{array}$ & $\begin{array}{l}-0.413 \\
(0.217)\end{array}$ & $\begin{array}{c}0.137 \\
(0.084)\end{array}$ & $\begin{array}{l}-0.133 \\
(0.100)\end{array}$ & $\begin{array}{l}0.000 \\
(.)\end{array}$ & $\begin{array}{c}0.000 \\
(.)\end{array}$ & $\begin{array}{l}0.970 \\
(0.434)\end{array}$ & $\begin{array}{l}-0.058 \\
(0.031)\end{array}$ \\
\hline $\begin{array}{l}\text { Observations } \\
\text { p-value } \\
\text { R-squared (within) }\end{array}$ & $\begin{array}{c}16 \\
\cdot \\
0.056\end{array}$ & $\begin{array}{c}73 \\
0.049 \\
0.247 \\
\end{array}$ & $\begin{array}{c}77 \\
0.154 \\
0.114 \\
\end{array}$ & $\begin{array}{c}46 \\
0.431 \\
0.309 \\
\end{array}$ & $\begin{array}{c}12 \\
0.466 \\
0.142 \\
\end{array}$ & $\begin{array}{c}12 \\
0.490 \\
0.015 \\
\end{array}$ & $\begin{array}{c}18 \\
\cdot \\
0.786 \\
\end{array}$ & $\begin{array}{c}81 \\
0.039 \\
0.035 \\
\end{array}$ \\
\hline
\end{tabular}

GDP = gross domestic product. Note: Fixed-effects estimation with country-fixed effects included. Robust standard errors in parentheses. ***, **, and *: $1 \%, 5 \%$, and $10 \%$ levels of significance. Source: Authors calculation. 
Table A8: Past Fiscal Adjustment, Growth, and Development Outcomes

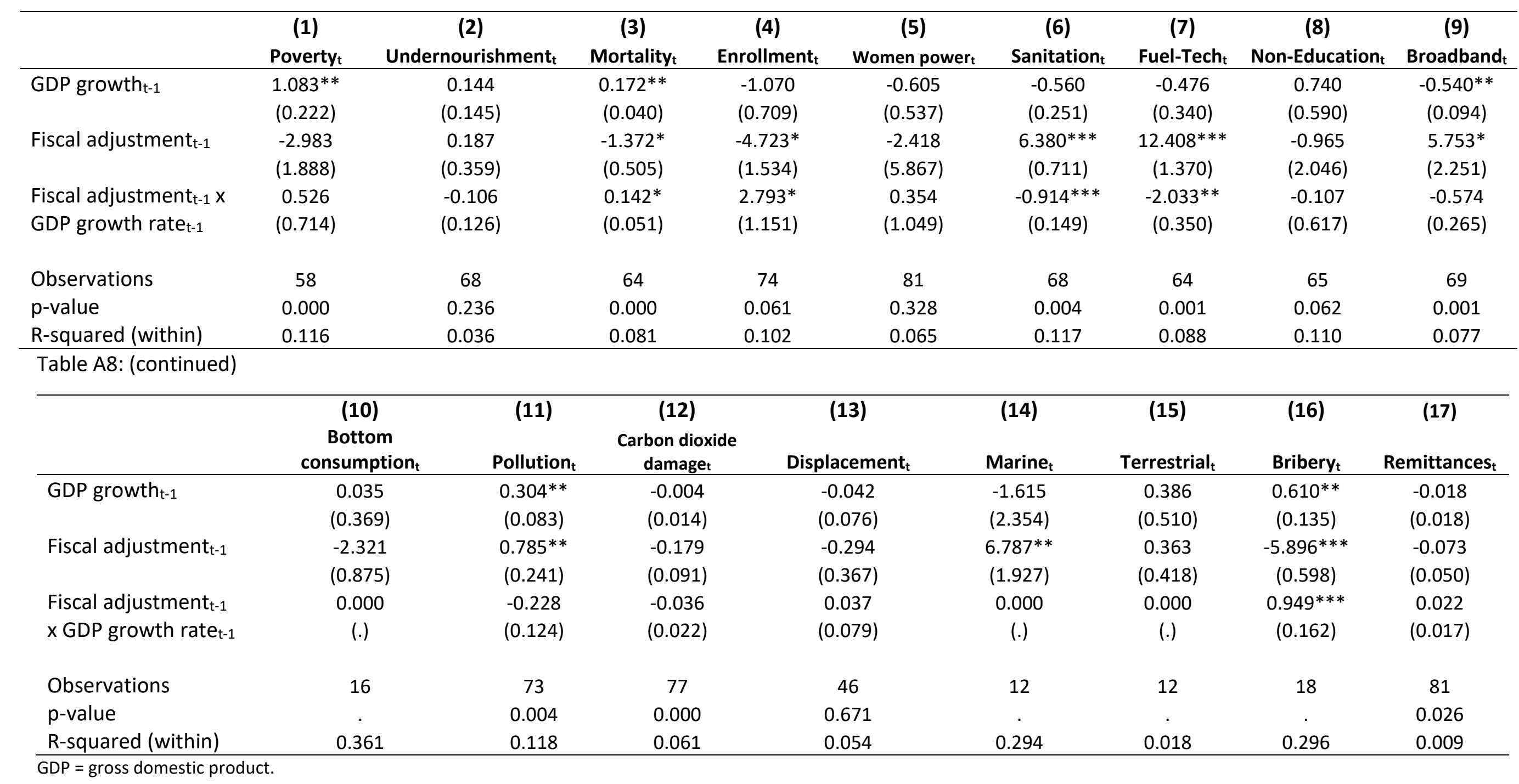

Note: Fixed-effects estimation with country-fixed effects included. Robust standard errors in parentheses. ${ }^{* * *}$, **, and *: $1 \%, 5 \%$, and $10 \%$ levels of significance. Source: Authors calculation. 
Table A9: Large Fiscal Impulses and Tax Components

\begin{tabular}{|c|c|c|c|c|c|c|c|c|}
\hline & \multicolumn{4}{|c|}{ Fiscal stimuli ${ }_{t}$} & \multicolumn{4}{|c|}{ Fiscal adjustment $_{\mathrm{t}}$} \\
\hline & (1) & (2) & (3) & (4) & (5) & (6) & (7) & (8) \\
\hline Personal income tax $x_{t+1}$ & $\begin{array}{c}0.058 \\
(0.049)\end{array}$ & & & & $\begin{array}{c}0.039 \\
(0.073)\end{array}$ & & & \\
\hline Corporate income tax $x_{t+1}$ & $\begin{array}{c}0.003 \\
(0.056)\end{array}$ & & & & $\begin{array}{c}0.048 \\
(0.058)\end{array}$ & & & \\
\hline Other direct taxes $\mathrm{s}_{\mathrm{t}+1}$ & $\begin{array}{l}-0.242 \\
(0.220)\end{array}$ & & & & $\begin{array}{l}-0.383 \\
(0.314)\end{array}$ & & & \\
\hline Direct taxes ${ }_{t+1}$ & & $\begin{array}{c}0.025 \\
(0.050)\end{array}$ & & & & $\begin{array}{c}0.046 \\
(0.041)\end{array}$ & & \\
\hline Indirect taxes $\mathrm{s}_{\mathrm{t}+1}$ & $\begin{array}{l}-0.077 \\
(0.055)\end{array}$ & $\begin{array}{l}-0.072 \\
(0.049)\end{array}$ & & & $\begin{array}{c}0.011 \\
(0.036)\end{array}$ & $\begin{array}{l}0.008 \\
(0.035)\end{array}$ & & \\
\hline Social contributions $_{\mathrm{t}+1}$ & $\begin{array}{c}-0.218^{* *} \\
(0.066)\end{array}$ & $\begin{array}{c}-0.232 * * \\
(0.060)\end{array}$ & & & $\begin{array}{l}-0.018 \\
(0.014)\end{array}$ & $\begin{array}{l}-0.033 \\
(0.017)\end{array}$ & & \\
\hline Personal income tax $x_{t-1}$ & & & $\begin{array}{c}0.019 \\
(0.037)\end{array}$ & & & & $\begin{array}{l}-0.054 \\
(0.030)\end{array}$ & \\
\hline Corporate income tax $\mathrm{t}_{\mathrm{t}-1}$ & & & $\begin{array}{c}0.095 * * * \\
(0.007)\end{array}$ & & & & $\begin{array}{l}-0.039 \\
(0.036)\end{array}$ & \\
\hline Other direct taxes ${ }_{t-1}$ & & & $\begin{array}{c}-0.225^{* * *} \\
(0.027)\end{array}$ & & & & $\begin{array}{c}-0.632 * * * \\
(0.086)\end{array}$ & \\
\hline Direct taxes $\mathrm{t}_{\mathrm{t}-1}$ & & & & $\begin{array}{c}0.067^{* *} \\
(0.018)\end{array}$ & & & & $\begin{array}{l}-0.043 \\
(0.045)\end{array}$ \\
\hline Indirect taxes ${ }_{t-1}$ & & & $\begin{array}{c}0.031 \\
(0.092)\end{array}$ & $\begin{array}{c}0.015 \\
(0.076)\end{array}$ & & & $\begin{array}{l}-0.007 \\
(0.060)\end{array}$ & $\begin{array}{l}-0.014 \\
(0.064)\end{array}$ \\
\hline Social contributions $\mathrm{t}-1$ & & & $\begin{array}{c}-0.089 * * \\
(0.020)\end{array}$ & $\begin{array}{c}-0.087^{* *} \\
(0.017)\end{array}$ & & & $\begin{array}{c}-0.103^{*} \\
(0.037)\end{array}$ & $\begin{array}{c}-0.135^{* *} \\
(0.035)\end{array}$ \\
\hline Observations & 77 & 77 & 81 & 81 & 77 & 77 & 81 & 81 \\
\hline$p$-value & . & 0.010 & . & 0.000 & & 0.184 & . & 0.099 \\
\hline R-squared (within) & 0.142 & 0.124 & 0.137 & 0.097 & 0.054 & 0.025 & 0.124 & 0.059 \\
\hline
\end{tabular}

Note: Explanatory variables are cyclically adjusted. Fixed effects estimation with country-fixed effects included. Robust standard errors in parentheses. ${ }^{* * *}, * *$, and $*: 1 \%, 5 \%$, and $10 \%$ levels of significance. Source: Authors calculation. 
Table A10: Large Fiscal Impulses and Expense Components

\begin{tabular}{|c|c|c|c|c|c|c|c|c|}
\hline & \multicolumn{4}{|c|}{ Fiscal stimuli $i_{t}$} & \multicolumn{4}{|c|}{ Fiscal adjustment $_{t}$} \\
\hline & (1) & (2) & (3) & (4) & (5) & (6) & (7) & (8) \\
\hline Wage $_{t+1}$ & $\begin{array}{c}0.066 \\
(0.043)\end{array}$ & & & & $\begin{array}{c}0.020 \\
(0.031)\end{array}$ & & & \\
\hline Non-wage $_{t+1}$ & $\begin{array}{c}0.065 \\
(0.031)\end{array}$ & & & & $\begin{array}{c}-0.059 \\
(0.056)\end{array}$ & & & \\
\hline Gov. consumption expenditure $\mathrm{t}_{t+1}$ & & $\begin{array}{c}0.066 \\
(0.036)\end{array}$ & & & & $\begin{array}{c}-0.016^{*} \\
(0.006)\end{array}$ & & \\
\hline Subsidies $_{t+1}$ & $\begin{array}{l}-0.018 \\
(0.037)\end{array}$ & $\begin{array}{l}-0.018 \\
(0.034)\end{array}$ & & & $\begin{array}{c}-0.070 \\
(0.060)\end{array}$ & $\begin{array}{l}-0.083 \\
(0.048)\end{array}$ & & \\
\hline Transfer $_{t+1}$ & $\begin{array}{c}-0.071 \\
(0.049)\end{array}$ & $\begin{array}{l}-0.071 \\
(0.048)\end{array}$ & & & $\begin{array}{c}-0.060^{*} \\
(0.022)\end{array}$ & $\begin{array}{c}-0.073 * * \\
(0.015)\end{array}$ & & \\
\hline Wage $_{t-1}$ & & & $\begin{array}{l}-0.020 \\
(0.046)\end{array}$ & & & & $\begin{array}{l}0.042^{*} \\
(0.016)\end{array}$ & \\
\hline Non-wage $_{t-1}$ & & & $\begin{array}{c}0.002 \\
(0.042)\end{array}$ & & & & $\begin{array}{c}0.003 \\
(0.017)\end{array}$ & \\
\hline Gov. consumption expenditure $t_{t-1}$ & & & & $\begin{array}{l}-0.010 \\
(0.024)\end{array}$ & & & & $\begin{array}{c}0.025 \\
(0.016)\end{array}$ \\
\hline Subsidies $\mathrm{t}-1$ & & & $\begin{array}{c}0.029 \\
(0.050)\end{array}$ & $\begin{array}{c}0.031 \\
(0.054)\end{array}$ & & & $\begin{array}{l}-0.009 \\
(0.025)\end{array}$ & $\begin{array}{l}-0.013 \\
(0.027)\end{array}$ \\
\hline Transfer $_{\mathrm{t}-1}$ & & & $\begin{array}{l}-0.018 \\
(0.039)\end{array}$ & $\begin{array}{l}-0.012 \\
(0.045)\end{array}$ & & & $\begin{array}{l}-0.071 \\
(0.042)\end{array}$ & $\begin{array}{l}-0.080 \\
(0.047)\end{array}$ \\
\hline Observations & 77 & 77 & 81 & 81 & 77 & 77 & 81 & 81 \\
\hline$p$-value & . & 0.292 & . & 0.285 & . & 0.061 & . & 0.253 \\
\hline R-squared (within) & 0.059 & 0.059 & 0.009 & 0.008 & 0.084 & 0.074 & 0.029 & 0.026 \\
\hline
\end{tabular}

Note: Explanatory variables are cyclically adjusted. Fixed effects estimation with country-fixed effects included. Robust standard errors in parentheses. ${ }^{* * *},{ }^{* *}$, and $*: 1 \%, 5 \%$, and $10 \%$ levels of significance. Source: Authors calculation. 
Table A11: Tax/Expense Components and Fiscal Stimuli/Adjustment

\begin{tabular}{|c|c|c|c|c|c|c|c|c|c|c|}
\hline & $\begin{array}{l}(1) \\
P T_{t}\end{array}$ & $\begin{array}{l}\text { (2) } \\
\mathrm{PIT}_{\mathrm{t}}\end{array}$ & $\begin{array}{l}\text { (3) } \\
\mathrm{CIT}_{\mathrm{t}}\end{array}$ & $\begin{array}{l}\text { (4) } \\
\mathrm{ClT}_{\mathrm{t}}\end{array}$ & $\begin{array}{c}\text { (5) } \\
\text { other }\end{array}$ & $\begin{array}{c}(6) \\
\text { Other }_{t}\end{array}$ & $\begin{array}{c}\text { (7) } \\
\text { INDT }_{t}\end{array}$ & $\begin{array}{c}(8) \\
\text { INDT }_{t}\end{array}$ & $\begin{array}{l}\text { (9) } \\
\text { SSC }_{t}\end{array}$ & $\begin{array}{l}(10) \\
S^{\prime} C_{t}\end{array}$ \\
\hline Fiscal stimuli $\mathrm{t}_{\mathrm{t}-1}$ & $\begin{array}{c}0.267 \\
(0.344)\end{array}$ & & $\begin{array}{c}0.025 \\
(0.249)\end{array}$ & & $\begin{array}{c}-0.051^{*} \\
(0.016)\end{array}$ & & $\begin{array}{c}-0.331 \\
(0.300)\end{array}$ & & $\begin{array}{l}-0.408 \\
(0.412)\end{array}$ & \\
\hline Fiscal adjustment $_{\mathrm{t}-1}$ & & $\begin{array}{c}0.133 \\
(0.167)\end{array}$ & & $\begin{array}{c}0.423 \\
(0.451)\end{array}$ & & $\begin{array}{l}-0.069 \\
(0.039)\end{array}$ & & $\begin{array}{c}0.052 \\
(0.176)\end{array}$ & & $\begin{array}{c}-0.056 \\
(0.055)\end{array}$ \\
\hline Observations & 77 & 77 & 77 & 77 & 77 & 77 & 77 & 77 & 77 & 77 \\
\hline$p$-value & 0.494 & 0.484 & 0.926 & 0.418 & 0.050 & 0.177 & 0.350 & 0.788 & 0.395 & 0.383 \\
\hline R-squared (within) & 0.013 & 0.003 & 0.000 & 0.023 & 0.016 & 0.031 & 0.024 & 0.001 & 0.096 & 0.002 \\
\hline
\end{tabular}

Table A11: (continued)

\begin{tabular}{|c|c|c|c|c|c|c|c|c|}
\hline & $\begin{array}{c}\text { (11) } \\
\text { Wage }_{t}\end{array}$ & $\begin{array}{c}(12) \\
\text { Wage }_{t}\end{array}$ & $\begin{array}{c}\text { (13) } \\
\text { Non_wage }\end{array}$ & $\begin{array}{c}\text { (14) } \\
\text { Non_wage }\end{array}$ & $\begin{array}{c}\text { (15) } \\
\text { Subsidies }_{\mathrm{t}}\end{array}$ & $\begin{array}{c}\text { (16) } \\
\text { Subsidies }_{\mathrm{t}}\end{array}$ & $\begin{array}{c}\mathbf{( 1 7 )} \\
\text { Transfer_hat }\end{array}$ & $\begin{array}{c}\text { (18) } \\
\text { Transfer_hat }\end{array}$ \\
\hline Fiscal stimuli $\mathrm{i}_{\mathrm{t}-1}$ & $\begin{array}{l}0.512^{*} \\
(0.183)\end{array}$ & & $\begin{array}{l}0.396 \\
(0.169)\end{array}$ & & $\begin{array}{l}-0.131 \\
(0.205)\end{array}$ & & $\begin{array}{c}0.036 \\
(0.163)\end{array}$ & \\
\hline Fiscal adjustment $_{\mathrm{t}-1}$ & & $\begin{array}{l}-0.158 \\
(0.117)\end{array}$ & & $\begin{array}{l}-0.593 \\
(0.357)\end{array}$ & & $\begin{array}{l}-0.282 \\
(0.356)\end{array}$ & & $\begin{array}{l}-0.535^{*} \\
(0.195)\end{array}$ \\
\hline Observations & 77 & 77 & 77 & 77 & 77 & 77 & 77 & 77 \\
\hline$p$-value & 0.068 & 0.272 & 0.102 & 0.195 & 0.568 & 0.486 & 0.839 & 0.071 \\
\hline R-squared (within) & 0.037 & 0.004 & 0.022 & 0.051 & 0.005 & 0.022 & 0.000 & 0.049 \\
\hline
\end{tabular}

Note: Dependent variables are cyclically adjusted. Fixed effects estimation with country-fixed effects included. Robust standard errors in parentheses. ${ }^{* * *}, * *$, and $*: 1 \%, 5 \%$, and $10 \%$ levels of significance. Source: Authors calculation. 